\title{
ESSAY
}

\section{FIRMS, COURTS, AND REPUTATION MECHANISMS: TOWARDS A POSITIVE THEORY OF PRIVATE ORDERING}

\author{
Barak D. Richman*
}

\begin{abstract}
This Essay formulates a positive model that predicts when commercial parties will employ private ordering to enforce their agreements. The typical enforcement mechanism associated with private ordering is the reputation mechanism, in which a merchant community punishes parties in breach of contract by denying them future business. The growing private ordering literature argues that these private enforcement mechanisms can be superior to the traditional, less efficient enforcement measures provided by public courts. However, previous comparisons between public and private contractual enforcement have presented a misleading dichotomy by failing to consider a third enforcement mechanism: the vertically integrated firm.

This Essay develops a model that comprehensively addresses three distinct types of enforcement mechanisms-firms, courts, and reputation-based private ordering. The model rests on a synthesis of transaction cost economics, which compares the efficiencies of firms versus markets, and the private ordering literature, which compares the efficiencies of public courts versus private ordering. It hypothesizes that private ordering will arise when agreements present enforcement difficulties, high-powered market incentives are important, and the costs of entry barriers are low. The Essay then conducts an illustrative test by comparing the model's predictions to documented instances of private ordering.
\end{abstract}

\section{TABLE OF CONTENTS}

INTRODUCTION

I. Shasta County Ranchers, Ultra-Orthodox Jews, and America's Fishmongers: The Many Faces of Private Ordering and Its Encounter with Modernity ........ 2333

II. Firms, Courts, and Reputation Mechanisms........... 2337

A. Public Versus Private Ordering .............. 2338

B. Firms Versus Markets ..................... 2348

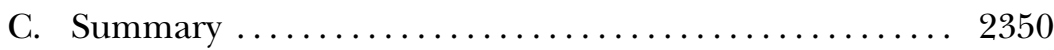

III. A Test with Preliminary Evidence ................... 2351

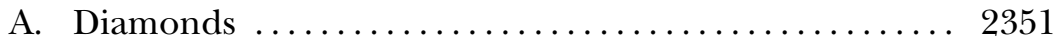

* Please send all correspondence to richman@law.duke.edu. My deep thanks go to Robert Cooter, Rui de Figueiredo, Jr., Tracy Lewis, Arti Rai, Robert Scott, Howard Shelanski, Pablo Spiller, George Triantis, Oliver Williamson, and the participants at the University of Virginia Law and Economics Workshop for their very helpful comments. The usual disclaimers apply. 
B. Cotton................................ 2354

C. Global Middlemen: California's Mexican Merchants, Eleventh-Century Maghribi Traders, and Malaysia's Chinese Networks .......................... 2355

D. Social Norms and Professional Norms ............. 2357

IV. The Model and Its Antecedents: Transaction Cost Economics and Private Ordering ................... 2362

A. Transaction Cost Economics .................... 2363

B. Private Ordering Literature $\ldots \ldots \ldots \ldots \ldots \ldots \ldots \ldots . \ldots \ldots$

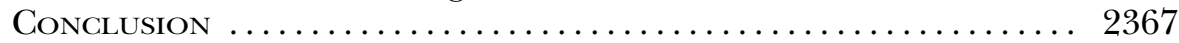

\section{INTRODUCTION}

The fascinating literature on private ordering, which aims to understand how parties enforce contracts without relying on public courts, unfortunately suffers from a damaging case of tunnel vision. This narrow focus is illustrated paradigmatically in the opening line of John McMillan and Christopher Woodruff's excellent survey, "Private Order Under Dysfunctional Public Order," an article that articulates how Asian merchants, American fish wholesalers, eleventh-century Maghribi traders, and many other merchant communities employ similar extralegal mechanisms to enforce agreements. ${ }^{1}$ McMillan and Woodruff begin: "Businesspeople need contractual assurance." ${ }^{2}$ A more accurate opening would have been "Businesspeople need transactional assurance," where contracts and assorted regimes of contract enforcement comprise only one category of devices that produce the needed assurance. Their terminology reveals the inclination, unfortunately common in the literature, to look singularly at contracts to the exclusion of alternative mechanisms that secure transactions; but it also presents an opportunity to relate the private ordering literature to the larger literature on transactional governance.

This Essay attempts to place private ordering within a broader theoretical context by weaving together two parallel strands of new institutional theory. The first lies in the original formulation of transaction cost economics, whose primary exercise contrasts the institutional attributes of firms against those of markets and predicts whether transactions will occur between autonomous agents or within a vertically integrated firm (alternatively coined the "make-or-buy question"). The second strand arises from the younger literature on private ordering, which compares the efficiencies of private (extralegal) contract enforcement with the more traditional use of public law and state-run courts. The analysis presented in this Essay is a straightforward, though previously unexplored, combination of these two approaches. It begins with the observa-

1. John McMillan \& Christopher Woodruff, Private Order Under Dysfunctional Public Order, 98 Mich. L. Rev. 2421, 2433-36 (2000) [hereinafter McMillan \& Woodruff, Dysfunctional Public Order].

2. Id. at 2421. 
tion that three distinct enforcement mechanisms emerge from these two literatures: (1) public courts, where transactors are autonomous and contract enforcement follows common contract law; (2) private ordering, where transactors are autonomous and employ extralegal mechanisms to enforce contracts; and (3) the vertically integrated firm, where transactions occur within a single legal entity and are secured through administrative control, and contract law plays no direct role in enforcement. Prior scholarship has neither examined all three governance mechanisms within a single model nor developed a comprehensive understanding of their comparative proficiencies in relation to each other. ${ }^{3}$

This Essay's primary objective is to begin formulating a positive model that predicts when one should expect to see systems of private law. It further aims to bring some coherence to the private ordering literature-illustrating that private law is not merely a convenient or necessary replacement for public courts but rather arises systematically and predictably —and to fill the theoretical blind spot created by the literature's legal-centric perspective. ${ }^{4}$ It proceeds as follows: Part I provides a brief overview of the recent literature on private ordering and identifies a conceptual puzzle that arises when systems of private law encounter and persist into modernity. Part II develops the predictive model. It explores three principal mechanisms employed to secure transactions-public

3. Gillian Hadfield's recent chapter deserves credit for including self-enforcement and vertical integration as two of the "many potential enforcement mechanisms available to support agreements," but her list of alternative governance mechanisms is discussed only sequentially and is not part of a comprehensive theory. See Gillian K. Hadfield, Contract Law is Not Enough: The Many Legal Institutions That Support Contractual Commitments, in Handbook of New Institutional Economics (Claude Menard \& Mary Shirley eds., forthcoming 2004). Yochai Benkler's work, Coase's Penguin, or, Linux and The Nature of the Firm, 112 Yale L.J. 369, 371-74 (2002), constitutes a related effort to understand unusual systems of organization within the market-versus-firm framework. I relate his model to my own in Part III.

4. See Marc Galanter, Justice in Many Rooms: Courts, Private Ordering, and Indigenous Law, $19 \mathrm{~J}$. Legal Pluralism 1, 17-21 (1981). Galanter was an early critic of what he called "legal centralism," a label he borrowed from John Griffiths, What is Legal Pluralism?, 24 J. Legal Pluralism 1, 3 (1986), and a concept explored by a few others. See, e.g., Robert D. Cooter, Structural Adjudication and the New Law Merchant: A Model of Decentralized Law, 14 Int'l Rev. L. \& Econ. 215, 215-18 (1994) [hereinafter, Cooter, Structural Adjudication] (comparing the inefficiencies of centralized lawmaking to those of centralized economic planning, and arguing that judges should defer to regional customary norms). However, Galanter uses the term slightly differently from the way it is used here. Galanter criticizes a "state-centered view of the legal phenomena," in which scholars tend to discuss only those legal instruments found in public courts, to the exclusion of the broad array of private enforcement mechanisms. Galanter, supra, at 1 \& n.1. Of course, as Part I discusses, there now is a healthy private ordering scholarship, and Galanter's criticism currently holds less force. The legal-centric perspective I critique is slightly different-it is a tendency to discuss only those enforcement mechanisms that relate to contracts and contract law, whether state-sponsored or privately developed, to the exclusion of the firm and other hierarchical institutions. I nonetheless borrow Galanter's term because while the substance of his critique differs from that of mine, the tendencies we address are virtually identical. 
courts, private ordering, and the firm-and examines the economic attributes of each. The key lesson from the model is that each governance mechanism has its own strengths and weaknesses, suggesting that each will systematically arise under different circumstances. Part III then illustratively tests the model developed in Part II by comparing its predictions to empirical findings in the literature on private ordering and merchant networks.

Lastly, Part IV compares the approach employed in this Essay with those approaches from this Essay's theoretical antecedents, and it is worth summarizing that Part and highlighting the Essay's theoretical contributions at the outset. This Essay's contribution to transaction cost economics is its extension of the transaction cost understanding of private ordering from the bilateral to the multilateral context. Such a shift makes necessary the introduction of an additional variable-entry barriers-to the transaction cost paradigm's staple considerations of incentive intensity and transactional security. Entry barriers do not hinder vertical integration, but they are inescapable in reputation-based private ordering. Consequently, the traditional transaction cost tradeoff-between high-powered incentives and transactional governance-is joined by a second tradeoff between high-powered incentives and entry barriers (private ordering has both and vertical integration has neither). Incorporating these two tradeoffs into a single analysis requires a departure from the traditional unidimensional model of governance mechanisms, which spans from markets to firms, and a move towards the slightly more complicated model described in Part II.

The Essay also notably departs from the current private ordering literature, particularly the scholarship of Lisa Bernstein. ${ }^{5}$ The current scholarship focuses on comparing the administrative costs of public versus private systems and generally concludes that certain merchant communities resort to self-enforcement and shun public courts as a means of garnering substantial administrative efficiencies. Consequently, these past analyses occupy the spaces within "the shadow of the law"

5. Lisa Bernstein's scholarship has spawned much of the recent attention to private ordering and privately tailored commercial law. See generally Lisa Bernstein, Merchant Law in a Merchant Court: Rethinking the Code's Search for Immanent Business Norms, 144 U. Pa. L. Rev. 1765 (1996) [hereinafter Bernstein, Business Norms] (describing the private arbitration system used by grain and feed traders); Lisa Bernstein, Opting out of the Legal System: Extralegal Contractual Relations in the Diamond Industry, 21 J. Legal Stud. 115 (1992) [hereinafter Bernstein, Diamonds] (same, for New York's diamond industry); Lisa Bernstein, Private Commercial Law in the Cotton Industry: Creating Cooperation Through Rules, Norms, and Institutions, 99 Mich. L. Rev. 1724 (2001) [hereinafter Bernstein, Cotton] (same, for the cotton industry).

6. Acknowledging the "shadow of the law" requires recognizing that the "principle contribution of courts to dispute resolution is providing a background of norms and procedures against which negotiations and regulation in both private and governmental settings take place." Galanter, supra note 4, at 6. Martin Shapiro deserves credit for first using the shadow imagery. See Martin Shapiro, Courts, in 5 Handbook of Political Science 321, 321 (Fred I. Greenstein \& Nelson W. Polsby eds., 1975) (noting general lack of 
where public courts are ultimately effective and cast down parameters within which private ordering and negotiation occur. This Essay argues that concerns over transactional assurance and contractual enforcement, not efforts to economize on administrative costs, drive merchant communities to private ordering (and to vertical integration as well). The focus is not on courts' costliness but on their ultimate futility, where administrative savings are merely the cart that follows the horse. This Essay's perspective draws parallels between the inclination towards private ordering and the attractiveness of vertical integration, and the result is a unified model that compares both instruments of securing transactions. These issues are elaborated in Part IV, and a brief conclusion follows.

Before going forward, it is important to add a cautionary remark. The model described herein is not designed to deal comprehensively with all the variables that may be relevant in predicting the efficacy or prevalence of private ordering. To be sure, private ordering systems are richly varied, and ultimately, any successful self-enforcing contractual regime must rely on many details that are not easily generalizeable or captured in a parsimonious model. ${ }^{7}$ Moreover, it should be noted that transaction cost economics is only one of several competing schools of organizational economics, and some (but not all) of the conclusions drawn here may not hold for those who subscribe to alternative understandings of the firm. ${ }^{8}$ Specifically, the assertion that vertically integrated

delineation between courts and other systems of adjudication); see also Galanter, supra note 4, at 8 n.11. The phrase was popularized by Robert Mnookin and Lewis Kornhauser in their study of negotiations surrounding divorce settlements. See Robert H. Mnookin \& Lewis Kornhauser, Bargaining in the Shadow of the Law: The Case of Divorce, 88 Yale L.J. 950, 968 (1979).

7. The prerequisites for an effective reputation-based system of private ordering are likely quite demanding. See Oliver E. Williamson, Economic Institutions: Spontaneous and Intentional Governance, 7 J.L. Econ. \& Org. 159, 167-69 (1991) [hereinafter Williamson, Spontaneous and Intentional Governance] (detailing the rigorous requirements to support trust-based exchange and the many factors that could disrupt such exchange systems). For a detailed illustration of one reputation-based system of exchange that does meet these prerequisites and that operates effectively, see Barak D. Richman, How Communities Create Economic Advantage: Jewish Diamond Merchants in New York 22-51 (Harvard Law and Econ. Discussion Paper No. 384, Sept. 2004), available at http://papers.ssrn.com/sol3/papers.cfm?abstract_id=349040 (on file with the Columbia Law Review).

8. Compare Oliver E. Williamson, The Economic Institutions of Capitalism (1985) [hereinafter Williamson, EIC] (examining economic organization through lens of transaction cost economics), with Oliver Hart, Firms, Contracts, and Financial Structure (1995) (describing economic organizations as allocations of residual control in property ownership rights), Michael C. Jensen \& William H. Meckling, Theory of the Firm: Managerial Behavior, Agency Costs and Ownership Structure, 3 J. Fin. Econ. 305 (1976) (presenting an agency theory of the firm), and Raghuram G. Rajan \& Luigi Zingales, The Firm as a Dedicated Hierarchy: A Theory of the Origins and Growth of Firms, 116 Q.J. Econ. 805 (2001) (articulating a theory of economic organization resting on dedicated hierarchies). It should be noted, however, that transaction cost economics has met a substantial amount of empirical success. See Howard A. Shelanski \& Peter G. Klein, Empirical Research in Transaction Cost Economics: A Review and Assessment, 11 J.L. 
firms exhibit attributes that are distinct from market contractual relations-which is held by transaction cost economics and is incorporated into this analysis - is not entirely shared by competing schools. ${ }^{9}$ For these reasons, the central message of this Essay lies not in the model's particular dimensions but in the general illustration that two important tensions that previously have only been addressed separately-namely, firm versus market on one hand and private versus public ordering on the otherare in fact part of a single equation and should be handled simultaneously in a comprehensive model. This general message, however, constitutes a contribution that comports with all schools of organizational economics, and though the specific hypotheses herein may not meet universal agreement, the progress towards a comprehensive model should.

\section{Shasta County Ranchers, Ultra-Orthodox Jews, and America's Fishmongers: The Many Faces of Private Ordering and ITS ENCOUNTER WITH MODERNITY}

Two characteristics make the private ordering literature rich for theoretical development. First, it constitutes a relatively new area of research, with its beginnings (or, if distant ancestors are given credit, ${ }^{10}$ its

Econ. \& Org. 335, 341-50 (1995) (reviewing several applications of transaction cost approach); see also Christopher S. Boerner \& Jeffrey T. Macher, Transaction Cost Economics: An Assessment of Empirical Research in the Social Sciences (last visited Sept. 20, 2004), available at http://www.msb.edu/faculty/jtm4/Papers/JLEO.pdf (on file with the Columbia Law Review) (reviewing transaction cost economics literature).

9. Jensen and Meckling, for example, describe the firm as a "nexus of a set of contracting relationships," which suggests that the transactional governance offered by a firm can be replicated by contract. Jensen \& Meckling, supra note 8, at 311.

10. For some antecedents to the recent private ordering literature, see generally Clifford Geertz, The Bazaar Economy: Information and Search in Peasant Marketing, 68 Am. Econ. Rev. 28, 30-31 (1978) (implying that search methods used by market actors serve as enforcement mechanisms in absence of reliable courtroom dispute resolution techniques); Stewart Macaulay, Non-Contractual Relations in Business: A Preliminary Study, 28 Am. Soc. Rev. 55, 60-62 (1963) (making the important observation that much contract enforcement occurs outside courtrooms); Sally Falk Moore, Law and Social Change: The Semi-Autonomous Social Field as an Appropriate Subject of Study, 7 L. \& Soc'y Rev. 719, 742-45 (1973) (describing rules that are enforceable both in conjunction with and absent state power). These early works made the important observation that much contract enforcement occurs outside the courtroom (or, in the case of developing countries, despite the lack of a reliable courtroom). These works were followed by scholarship in the 1990s which formulated the first assessments of the efficiency of private enforcement.

A related literature on relational contracts, where both the terms and the enforcement of an agreement are embedded within a bilaterally dependent relationship, emerged in the 1970s and involved both legal and economic scholars. Ian Macneil is heralded as the pioneer who identified the important distinction between discrete and relational transactions. Ian R. Macneil, The Many Futures of Contracts, 47 S. Cal. L. Rev. 691, 694-96 (1974) (arguing that prevalence of "relational patterns" in modern economic society "justifies examination of the many futures of contracts in relations and their contrast with the singular future of contract in discrete transactions"). He later articulated 
recent resurgence) reaching back only to the early 1990s. Second, it contains genuinely interesting stories. Robert Ellickson, in Order Without Law, ${ }^{11}$ contributed to both features when he observed that Shasta County's ranchers-contrary to the predictions of both Ronald Coase's seminal 1967 article $^{12}$ and much of the law and economics literatureignore legal rules and settle disputes relying on their own principles (which Ellickson argues are wealth maximizing). Other early works include Avner Greif's studies of eleventh-century Maghribi traders, ${ }^{13}$ Lisa Bernstein's examination of Ultra-Orthodox Jewish diamond merchants, ${ }^{14}$

the contrasting legal needs of both types of transactions and, appropriately, neoclassical law's recognition of those differences. Ian R. Macneil, Contracts: Adjustment of LongTerm Economic Relations Under Classical, Neoclassical, and Relational Contract Law, 72 Nw. U. L. Rev. 854, 859-76 (1978). Charles Goetz and Robert Scott offered a valuable refinement of how relational contracts arise and the legal problems that follow. See Charles J. Goetz \& Robert E. Scott, Principles of Relational Contracts, 67 Va. L. Rev. 1089, 1095-1111 (1981) (identifying conditions that produce variations in the nature and form of relational contracts). Economists employed the relational contract model to describe kinship or clan-based transactions, public utility regulation, franchise agreements, and reciprocal trading agreements. See Yoram Ben-Porath, The F-Connection: Families, Friends, and Firms and the Organization of Exchange, 6 Population \& Dev. Rev. 1, 1 (1980) (describing the family as "the locale of transactions in which identity dominates"); Victor P. Goldberg, Regulation and Administered Contracts, 7 Bell J. Econ. 426, 426-27 (1976) (describing public utility regulation as relational "administered" contracts featuring ongoing relationships and reliance by individuals on agents); Benjamin Klein, Transaction Cost Determinants of "Unfair" Contractual Arrangements, 70 Am. Econ. Rev. 356, 358-60 (1980) (analyzing characteristics of contractual relationships between franchisors and franchisees); Oliver E. Williamson, Credible Commitments: Using Hostages to Support Exchange, 73 Am. Econ. Rev. 519, 530 (1983) [hereinafter Williamson, Credible Commitments] (arguing that expropriation hazards within the "hostage model" can be avoided by expanding the contracting relationship from unilateral to bilateral); Oliver E. Williamson, Franchise Bidding for Natural Monopolies-In General and with Respect to CATV, 7 Bell J. Econ. 73, 91 (1976) (describing public utility regulation as a long-term contract within which adaptations to inevitably changing circumstances require institutional support). This valuable literature continues to inform our economic and legal understanding of bilateral transactions that deviate from the classical contract paradigm and inherently involve some aspect of self-enforcement. See generally Oliver E. Williamson, Mechanisms of Governance 95-97, 370 (1996) [hereinafter Williamson, MOG] (outlining elements of identity, autonomy, and bilateral dependence in neoclassical contract law).

11. Robert C. Ellickson, Order Without Law: How Neighbors Settle Disputes 52-56 (1991).

12. R.H. Coase, The Problem of Social Costs, 3 J.L. \& Econ. 1, 3-8 (1960) (theorizing that liability rules determine the direction of wealth transfers, if not the ultimate allocation of resources, in the resolution of conflicts over competing property uses).

13. See Avner Greif, Contract Enforceability and Economic Institutions in Early Trade: The Maghribi Traders' Coalition, 83 Am. Econ. Rev. 525, 527-28 (1993) [hereinafter Greif, Contract Enforceability] (describing structures governing Maghribi traders); Avner Greif, Reputation and Coalitions in Medieval Trade: Evidence on the Maghribi Traders, 49 J. Econ. Hist. 857, 858 (1989) [hereinafter Greif, Reputation and Coalitions] (examining institutions that enabled eleventh-century Mediterranean merchants to enforce contracts with overseas agents).

14. Bernstein, Diamonds, supra note 5. 
and Milgrom, North, and Weingast's exploration into Medieval Europe's merchant guilds. ${ }^{15}$ Each of these works explored fascinating merchant communities and uncovered similarly organized reputation mechanisms that induced certain mutually and socially beneficial behavior (in Shasta County, a particular code of neighborly conduct, and in the latter three works, the fulfillment of contractual obligations). The basic underlying structures were the same in each of these communities: Parties benefit from ongoing transactions with their colleagues; in each transaction, parties have an opportunity to cheat their counterparts; if a party cheats any other party, that party's misconduct becomes known throughout the community; and no one will transact with any individual known to have cheated in the past. Thus, a party's good reputation ensures the opportunity to benefit from future transactions, and inversely, the prospect of future beneficial transactions induces cooperative behavior. In gametheoretic language, the assurance of ex post sanctions against cheaters allows transactors to commit credibly to fellow merchants that they will fulfill their contractual duties.

Over a dozen other articles followed, each identifying a merchant community that used reputation mechanisms to enforce commercial agreements. ${ }^{16}$ An important feature emerging from this literature is the discovery that each of the different systems of private enforcement falls into one of two categories: those that arise where private law is employed because reliable state-sponsored contract enforcement is unavailable, and those that arise where public courts are available but where private law is preferable. Merchant communities that fall into the first category include those in early commercial societies, which predated modern state institutions and contract law, ${ }^{17}$ modern-day communities in third-world societies where contract law and independent judiciaries are not yet well developed, ${ }^{18}$ and members of mafia or other criminal networks whose

15. Paul R. Milgrom et al., The Role of Institutions in the Revival of Trade: The Law Merchant, Private Judges, and the Champagne Fairs, 2 Econ. \& Pol. 1, 4-6 (1990) (describing the use of private judges by European merchants during early middle ages). This body of scholarship is particularly important because it models how coordination among a merchant community can support multilateral exchange without relying on statesponsored courts. See Milgrom et al., supra; Greif, Contract Enforceability, supra note 13; Greif, Reputation and Coalitions, supra note 13.

16. See McMillan \& Woodruff, Dysfunctional Public Order, supra note 1, at 2443, 2444 tbl.2, for a thorough overview of the recent literature.

17. See, e.g., Karen Clay, Trade Without Law: Private-Order Institutions in Mexican California, 13 J.L. Econ. \& Org. 202, 202 (1997) (examining private contractual enforcement among Spanish merchants in $1830 \mathrm{~s}$ California); Greif, Contract Enforceability, supra note 13, at 528-31 (same, for eleventh-century Mediterranean merchants); Greif, Reputation and Coalitions, supra note 13, at 860 (same); Milgrom et al., supra note 15, at 4-6 (modeling private adjudication system used by medieval European traders).

18. See, e.g., Marcel Fafchamps, The Enforcement of Commercial Contracts in Ghana, 24 World Dev. 427, 442-43 (1996) (discussing the limited role legal institutions play in enforcing contracts between Ghanaian firms); John McMillan \& Christopher 
transactions involve illegal activity (since state courts refuse to enforce contracts that involve illegalities). ${ }^{19}$ These commercial networks resort to self-enforcement because state contractual enforcement is not a reliable option. Similarly, the absence of reliable legal institutions also precludes these merchant communities from employing vertical integration to govern transactions. ${ }^{20}$ The lack of sophisticated financial markets in developing societies requires difficult self-financing for acquisitions, and the inability (or, for illegal activity, refusal) of courts to enforce property rights effectively precludes the possibility of pro rata ownership between arms-length transactors. Thus, prelegal societies have relied on relational contracts and private ordering to secure transactions because of the unavailability of other mechanisms such as public law and vertical integration. This first category of communities reveals insights into the ancestors of commercial societies and the utility of modern courts. Most scholars characterize these enforcement mechanisms as prelaw orders that are easily supplanted when reliable public ordering emerges. ${ }^{21}$

The second category of reputation-based enforcement mechanisms poses a different and more difficult challenge. In these instances, a particular merchant community, which often comprises an entire industry segment, deliberately declines to rely on available court remedies to enforce agreements. Lisa Bernstein is a leader in uncovering such systems, including those supporting the Diamond Dealers Club of New York, ${ }^{22}$ the National Grain and Feed Association, ${ }^{23}$ and the assorted trade associations that govern America's cotton merchants. ${ }^{24}$ McMillan and Woodruff uncover similarly organized reputation systems that enforce agreements

Woodruff, Dispute Resolution Without Courts in Vietnam, 15 J.L. Econ. \& Org. 637, 640-41 (1999) [hereinafter McMillan \& Woodruff, Vietnam] (describing the use of reputation mechanisms and private ordering to enforce contracts between Vietnamese businesspeople); Christopher Woodruff, Contract Enforcement and Trade Liberalization in Mexico's Footwear Industry, 26 World Dev. 979, 984-85 (1998) (tracing the evolution of private contract enforcement in the Mexican footwear industry as trade barriers were liberalized).

19. See, e.g., Curtis J. Milhaupt \& Mark D. West, The Dark Side of Private Ordering: An Institutional and Empirical Analysis of Organized Crime, 67 U. Chi. L. Rev. 41, 48-51 (2000) (arguing that organized crime provides "response to inefficiencies in the property rights and enforcement framework supplied by the state"); Richman, supra note 7, at 66 .

20. See McMillan \& Woodruff, Vietnam, supra note 18, at 644 (attributing, in part, the lack of vertical integration among Vietnam's firms to the country's primitive legal institutions).

21. See Avner Greif, Institutions and Impersonal Exchange: The European Experience 25-34 (John M. Olin Program in Law and Econ., Working Paper No. 284, 2004), available at http://papers.ssrn.com/sol3/papers.cfm?abstract_id=548783 (on file with the Columbia Law Review) [hereinafter Greif, Impersonal Exchange].

22. See Bernstein, Diamonds, supra note 5, at 124-30.

23. See Bernstein, Business Norms, supra note 5, at Part I.

24. See Bernstein, Cotton, supra note 5, at Part I.A. 
made to America's fresh-fish wholesalers and New York's dress manufacturers..$^{25}$

The presence of these two contrasting categories of private ordering creates an interesting riddle. If early systems of private ordering arose because of the absence of reliable courts, then why do some systems of private ordering persist into modern societies?26 Conversely, if private legal systems enjoy certain efficiencies over public courts, which Lisa Bernstein's work carefully articulates, why does economic research overwhelmingly indicate that reliable public courts are central to facilitating economic growth, ${ }^{27}$ and correspondingly, why did most instances of private ordering dissolve with the emergence of public courts? Herein is revealed perhaps another misstatement by McMillan and Woodruff: They attribute the emergence of private ordering to the "dysfunctional" nature of public courts (their survey article is entitled "Private Order Under Dysfunctional Public Order").28 But that's too categorical. We see variation-and upon closer examination, a systematic variation-in both the persistence and the dissolution of private ordering because both private and public legal systems have discernible strengths and shortcomings. Consequently, a positive model with identifiable variables should be able to predict when parties will rely on private ordering even after encountering modernity and obtaining access to reliable public courts.

\section{Firms, Courts, and Reputation Mechanisms}

Constructing a predictive model for private ordering requires understanding not only the economic properties of such private systems, their strengths and shortcomings, but also their structural alternatives. The two alternatives that receive attention here are state-sponsored courts and vertically integrated firms, and a simple series of comparisons among these three instruments of transactional governance serves as the model's foundations. This is the same skeletal methodology employed in much of

25. McMillan \& Woodruff, Dysfunctional Public Order, supra note 1, at 2436, 2441-42.

26. A popular hypothesis that accompanied examinations of underdeveloped legal systems was that, in fact, relational contracting and private ordering would inevitably succumb to public courts. See, e.g., P.J. Fitzgerald, Salmond on Jurisprudence \$§ 31-32 (12th ed. 1966); see also Cooter, Structural Adjudication, supra note 4, at 216 ("Many intellectuals believe that centralized law is inevitable, just as they once believed that socialism was inevitable.").

27. See, e.g., Douglass C. North, Institutions, Institutional Change and Economic Performance 110 (1990) ("We have long been aware that the tax structure, regulations, judicial decisions, and statute laws ... determine specific aspects of economic performance . . . ."); Avner Greif \& Eugene Kandel, Contract Enforcement Institutions: Historical Perspective and Current Status in Russia, in Economic Transition in Eastern Europe and Russia: Realities of Reform 291, 317-18 (Edward P. Lazear ed., 1995) ("In Russia today, the absence of an appropriate institutional infrastructure for contract enforcement is producing severe economic problems.").

28. McMillan \& Woodruff, Dysfunctional Public Order, supra note 1, at 2425. 
the transaction cost literature, ${ }^{29}$ and the underlying intuition is quite elementary: Each method of enforcement exhibits consistent institutional competencies that translate into certain relative strengths and weaknesses. Thus, each is comparatively more adept-i.e., transaction-cost minimizing - than the others for certain transactions, so we will see each arise systematically to organize transactions of similar attributes. In short, the nature of the underlying transaction will consistently determine the superior method of enforcement. ${ }^{30}$

Examining the attributes and corresponding capabilities of each of the three distinct institutional arrangements-private ordering, state courts, and vertical integration-involves employing two rudimentary comparisons. The first, steeped in the private ordering literature, contrasts state courts and public law with private ordering; and the second, based on well-developed transaction cost models, compares markets and firms.

\section{A. Public Versus Private Ordering}

The literature on private ordering is chiefly limited to examining specific case studies where merchant communities enforce agreements without relying on state-sponsored courts. To the degree that these works compare systems of private law with public law, the comparison is limited to explaining why the selected industries shun public courts. ${ }^{31}$ Thus, the literature has generated a substantial, albeit self-selected, list of features of private law that generate efficiencies over the public courts.

Before proceeding to those specific efficiencies, it is useful to review the basic differences between public and private ordering. The primary difference is that public enforcement applies to all disputes. It employs a common body of contract law, and since it enjoys the backing of statesponsored coercion, it can require all losing parties to comply with its

29. For an articulation of the methodology, see Oliver E. Williamson, Comparative Economic Organization: The Analysis of Discrete Structural Alternatives, 36 Admin. Sci. Q. 269, 269 (1991). Note, however, that Williamson's three-way comparisons among markets, hierarchies, and hybrids lie across a unidimensional spectrum, where hybrids are intermediates between the market and hierarchy extremes. Though the methodology is the same, the three-way comparison here is different because none of the three structural alternatives-market, firm, and private ordering-is an intermediate of the other two.

30. This is a variation of the "discriminating alignment hypothesis" that serves as a foundation to transaction cost economics. See id. at 277. According to Williamson, the discriminating alignment hypothesis "holds that transactions, which differ in their attributes, are aligned with governance structures, which differ in their costs and competencies, in a discriminating (mainly, transaction-cost-economizing) way." Id.

31. One notable exception is Robert Cooter \& Janet T. Landa, Personal Versus Impersonal Trade: The Size of Trading Groups and Contract Law, 4 Int'l Rev. L. \& Econ. 15, 20 (1984), which identifies certain advantages in both impersonal court ordering and relational private ordering. This work stands out because it postulates an equilibrium that balances the comparative advantages of the two systems. Using a free entry equilibrium, it shows that if a group of traders surpasses an optimal size, defense of arms-length contracting in the public courts becomes superior to private enforcement mechanisms. Id. 
legal rulings. Private ordering, in contrast, requires voluntary cooperation by participating merchants. ${ }^{32}$ It applies a body of specialized law and procedures to merchants who voluntarily subject themselves to such rules, and it provides effective transactional security only because all participating members are committed to adhering to industry rules and complying with private arbitrators' rulings. ${ }^{33}$ Since failure to comply with these dictates precludes future business in the industry, losers of arbitration rulings will exhibit compliance only if the benefits from their future dealings within the merchant community will outweigh their immediate loss in arbitration.

This lattermost feature-prospects for future transactions inducing compliance with current contractual obligations-is a mainstay in the literature on private ordering. ${ }^{34}$ Thus, similar to the private judges of the

32. Private arbitration panels (such as the Memphis Cotton Exchange and the New York Diamond Dealers Club) generally invite state courts to enforce their rulings. See Bernstein, Diamonds, supra note 5, at 125; Bernstein, Cotton, supra note 5, at 1737 n.68. In fact, however, very few private disputes spill into state courts and are instead enforced exclusively through the threat of private, extralegal sanctions. Bernstein attributes this exclusivity of private enforcement to the likelihood that an individual who contests an arbitration decision and forces a fellow merchant to seek a ruling in state court will suffer doubly-by prompting his own expulsion from the trade association while additionally earning a reputation as a litigious, uncooperative member of the merchant community. See Bernstein, Diamonds, supra note 5, at 148; Bernstein, Cotton, supra note 5, at 1737-38. So, despite the alleged enforceability of the arbitration rulings in state court, the real enforcement power comes from private sanctions. Note that, regardless of the reach of state courts, this private power limits the reach of the arbitrators only to those beholden to the prospect of future transactions. This topic is revisited in Part III, infra.

33. Not all systems of private law have private judges or arbitrators. The absence of such adjudicators in some systems highlights the distinction between "spontaneous" and "organized" private ordering: In the former, communities police themselves and order arises spontaneously, whereas in the latter, order requires an organizing, central body that collects and disseminates players' reputational information. See McMillan \& Woodruff, Dysfunctional Public Order, supra note 1, at 2425-27; see also Williamson, Spontaneous and Intentional Governance, supra note 7, at 159 (noting that attention given to "largely invisible" spontaneous governance has overshadowed "the importance of intentional governance"). Ellickson's cattle ranchers present an example of spontaneous ordering, since the neighbors' social networks naturally facilitate gossip and information sharing that are sufficient to induce coordinated behavior. Alternatively, larger merchant communities—-such as New York's diamond merchants and Memphis's cotton brokersrequire organized private law, where a body of arbitrators determines where wrongdoing occurs and publicizes the identity of the wrongdoers.

Nonetheless, the proposition still holds for both spontaneous and organized private ordering: The reach of private ordering is limited to individuals committed to repeat interactions with the industry and/or merchant community.

34. Another "darker" form of private ordering relies not on reputations but on violence. See Milhaupt \& West, supra note 19, at 50. In theory, private ordering means nothing more than employing extralegal mechanisms to induce compliance, and reputation mechanisms are only a subset of private enforcement mechanisms. This Essay focuses on reputation mechanisms, however, since they play important roles in modern commerce and support variegated industries, whereas the role of violence (and other private mechanisms) is more limited. In addition to violence, reputation mechanisms remain important even in illegal networks. See Richman, supra note 7, at 49 (noting that 
Champaign Fairs described in the Milgrom, North, and Weingast model, ${ }^{35}$ arbitration rulings in private ordering systems serve more as mechanisms to signal the quality of a merchant's reputation than as genuine instruments to enforce contractual obligations. A merchant who is found by a private court to have breached a contract but fails to pay receives publicity as a bad actor, leading other merchants to respond to the public ruling by refusing to deal with the transgressor. ${ }^{36}$ The literature is replete with instances of such coordinated and collectively orchestrated punishments. ${ }^{37}$ In sum, public ordering employs the coercive power of the state, to which all actors are subject, and relies on standard contract law and litigation rules. In contrast, private ordering relies on reputation mechanisms, which can induce only members of a merchant community to comply, and exhibits separately created law and selected judges. These very different legal structures result in different qualities of performance. Their differences involve their respective costs of enforcement, efficacy of enforcement, and availability of entry. Each of these differences is discussed in turn.

Jewish community networks, which ably enforce executory contracts for diamond sales, have used "the same family and community relationships" to traffic illegal goods).

35. See Milgrom et al., supra note 15, at 3.

36. These private courts play indispensable roles in disseminating information about individual reputations. See id. (suggesting that private judges "transmit . . . information . . . to enable the reputation mechanism to function effectively"); see also Bernstein, Cotton, supra note 5, at 1745 (describing private legal system's reliance upon the social basis of trade and the flow of reputation related information throughout cotton industry); Richman, supra note 7, at 19 (stating that the New York Diamond Dealers Club "facilitate[s] a flow of information about market participants"). They enable reputation mechanisms to enforce agreements in merchant communities even as the communities grow. Cf. Lior Jacob Strahilevitz, Social Norms from Close-Knit Groups to Loose-Knit Groups, 70 U. Chi. L. Rev. 359, 365 n.31 (2003). Strahilevitz cautions that reputation mechanisms may weaken when relied upon beyond small communities like those in Shasta County. Reputation mechanisms, including those that rest upon social norms, can remain effective, though, when they spread accurate and necessary reputation information. Cooter and Landa identify a similar drawback to relational contracting, arguing that personalized trading networks become less advantageous as their size grows, see Cooter \& Landa, supra note 31, at 15-16, but information mechanisms may overcome this as well.

37. Since merchant circles correspond to closely knit communities, many coordinated sanctions harness social norms that inflict personal disutility. For one example of this effect, see Richman, supra note 7, at 40-54 (describing coordinated norms among diamond merchants in Orthodox Jewish community). Some examples of these coordinated punishments are especially colorful. Bernstein, Diamonds, supra note 5 , at 128 and Richman, supra note 7, at 20, describe sanctions in the diamond industry that resemble the Old West's "Wanted" posters, where the pictures of merchants who are found to owe debts are posted on the walls of each of the world's twenty-four diamond bourses. Once a dealer is known to have a bad debt, he will lose future business, face expulsion from the diamond bourses, and potentially suffer a denial of religious honors in the UltraOrthodox community. See Bernstein, Diamonds, supra note 5, at 128-30. Another example comes from the fishmongers of Accra, Ghana, where "women greet bad payers on the main fish market with screams and shouts, thereby sharing information instantly in a simple but effective fashion. Bad clients find it difficult to remain in the fish business because they are cut from the major source of supply." Fafchamps, supra note 18, at 441. 
1. Costs of Enforcement. - The early works by Ellickson and Bernstein described environments where public courts were available but intentionally shunned, begging an efficiency explanation for how, given particular circumstances, private law achieved greater efficiencies than public law. The answers from these early studies and the literature that followed, led chiefly by Lisa Bernstein's subsequent work, articulated efficiencies that resulted from dispute resolution techniques in systems of private law. ${ }^{38}$

There are three primary sources of efficiencies that private contract enforcement enjoys over the public court system. First, the private arbitration process exclusively involves industry insiders. The litigating parties are repeat players who are familiar with the arbitration process, the merchant community, and likely the arbitrators themselves. Such familiarity with the litigation process may reduce the administrative costs for the parties, but more importantly it maintains realistic expectations of arbitration results and enhances the predictability of outcomes. ${ }^{39} \mathrm{Of}$ additional significance is the fact that the arbitrators themselves are member merchants who possess industry expertise and specialized knowledge regarding industry transactions. This expertise makes the private arbitrators well equipped to serve as effective factfinders and positions them to tailor judgments specifically to match individual disputes. Consequently, relative to the capacities of public courts, arbitrators issue more factually accurate rulings and impose remedies more capable of appropriately punishing behavior. For example, most public courts are very hesitant to incorporate lost profits into expectation damages because doing so involves speculation that extends beyond the qualifications of judges and juries. ${ }^{40}$ One consequence of this refusal is that expectation damages undercompensate the breached party and therefore underdeter breach. Ar-

38. For a summary of this category of efficiencies and an overview of Lisa Bernstein's works, see Lisa Bernstein, Private Commercial Law, in 3 The New Palgrave Dictionary of Economics and the Law 108 (Peter Newman ed., 1998).

39. See Lisa Bernstein, The Questionable Empirical Basis of Article 2's Incorporation Strategy: A Preliminary Study, 66 U. Chi. L. Rev. 710, 773-74 (1999) (stating that one of most important functions of merchant-run arbitration tribunals is education of "members of the trade about the content of the rules and the contours of proper business practices"); see also Bernstein, Business Norms, supra note 5, at 1815-20 (describing efficiency gains of merchant adjudication of disputes among grain and feed merchants). Bernstein's extremely valuable work on the commercial importance of adjudicative predictability leads to a fascinating implication: that Karl Llewellyn's neoclassical approach to contract lawwhich is embodied in Article 2 of the UCC-is wrongheaded. Llewellyn's approach encourages adjudicators to deduce the originating motives behind a transaction. See, e.g., Karl N. Llewellyn, What Price Contract?-An Essay in Perspective, 40 Yale L.J. 704, 745 (1931) (exhorting courts to look to implied conditions of commercial understanding). In contrast, by restricting the range of possible interpretations of a certain agreement, and thus limiting an adjudicator's ability to second guess contractual intent, commercial law is able to increase judicial certainty. The predictability of specific litigation encourages parties to renegotiate and resume commercial dealings outside the courtroom.

40. This is a foundation in the common law and a staple in any first-year contracts course. See, e.g., Chi. Coliseum Club v. Dempsey, 265 Ill. App. 542, 549-50 (App. Ct. 1932). 
bitrators with industry expertise, however, are better positioned to approximate lost profits and routinely award them. Diamond industry arbitrators not only are able to award lost profits but are instructed to do so by industry rules. ${ }^{41}$

Second, private law can be tailored very specifically to the idiosyncratic needs and transactional challenges of a particular industry and can lead to identifiable efficiencies, including the facilitation of dispute resolution. For example, the National Grain and Feed Association (NGFA) developed clear, bright-line industry contract rules that directly address problematic issues in grain sales contracts and enable arbitrators to deliver prompt, predictable rulings. Consequently, NGFA rules create contractual certainty where the applicable common law would dictate less predictable results. ${ }^{42}$ Similarly, Diamond Dealers Club (DDC) bylaws require several formalities to consummate a diamond sale, including the invocation of specific words, in order to allow potential buyers to inspect merchandise while preemptively resolving the looming question of whether an agreement was formed. ${ }^{43}$

A third efficiency, drawing on the first two, is that private arbitration systems are able to act more swiftly and at lower costs than overloaded and procedure-laden public courts. Private arbitrators enjoy both a familiarity with the industry (including a familiarity with the kinds of disputes that commonly arise) and specially tailored procedural rules designed with a greater emphasis on speed than those that govern public courts. Arbitrators consequently require less background information and struggle with fewer administrative hurdles to deliver rulings.

These three advantages of private law-specialized judges, specialized substantive law, and specialized procedures-lead to faster, more accurate, and more predictable legal outcomes.

2. Efficacy of Enforcement. - Contract law is only as good as the degree to which litigants comply with its rulings. Public courts handle the challenge of enforcement by providing victorious parties with certain forceful tools to implement their judgments, including the ability to seize a losing party's assets or the ability to impose alternative sanctions such as jail and other equitable measures. But even these forceful measures are toothless to enforce certain kinds of agreements. The basic inadequacy of public courts for these particular agreements reveals a critical additional advantage that some private systems enjoy.

41. See Bernstein, Diamonds, supra note 5, at $136 \&$ n.45 (stating that while Diamond Dealers Club arbitration panels find it extremely difficult to calculate lost profits, they usually generously award punitive damages to compensate for alleged lost profits). According to the DDC bylaws, losing parties must also pay an additional fifteen percent of the arbitration award or $\$ 1,500$, whichever sum is greater, to compensate the victorious party for legal expenses. Diamond Dealers Club By-Laws, art. XII, § 12b (1999) (on file with the Columbia Law Review).

42. See Bernstein, Cotton, supra note 5, at 1739-44.

43. See Diamond Dealers Club By-Laws, supra note 41, at art. XVIII, §§ 1-5. 
Credit purchases for diamonds, for example, are one sort of transaction that public courts simply cannot enforce. ${ }^{44}$ Diamonds are portable, concealable, and universally valuable, rendering courts incapable of punishing a merchant who refuses to pay the seller and instead escapes with the diamonds to an unknown jurisdiction. Moreover, since brokering diamonds does not require substantial complementary investments, a fleeing diamond merchant would leave behind few assets for a court to seize and award to an abandoned seller. Because diamond merchants need to purchase and sell diamonds on credit, ${ }^{45}$ merchants require a legal system that can reliably enforce credit agreements.

Public law is incapable of credibly enforcing a second kind of agreement. As discussed above, public law and state courts suffer from substantial delays and often require significant amounts of time to resolve disputes. Consequently, a merchant would not find it economical to employ the public courts to enforce a contract that involves small dollar amounts and is time sensitive, leaving courts incapable of credibly enforcing such a contract.

These are the difficulties confronting America's fish wholesalers. Fish supplies are unpredictable, and fish, once caught, spoil quickly. As a result, wholesalers cannot plan future sales contracts, and once they purchase fish from boats that arrive into port, they must immediately sell their goods, often without securing payment or negotiating a secured contract. One fish dealer commented, "You're selling a melting ice cube. Today it's cod; tomorrow it's cat food .... . [We're] selling things that . . . drop[] in value by the hour. Twenty-eight cents a pound today; it's worth two cents a pound tomorrow." ${ }^{46}$ The short window of opportunity to execute a transaction compels sales on credit, but the costliness of enforcing those sales contracts through the public courts precludes effective ex post enforcement of the credit sales.

Public courts fail in a third instance, where contracts involve complex issues of quality that are difficult either to measure or to verify, particularly when the timeliness of compliance is critical. This is the situation for cotton mills. Mills are most efficient when they are constantly running, but since cotton involves substantial storage costs, most mills operate under just-in-time supply networks. ${ }^{47}$ In addition, to weave the

44. See Richman, supra note 7, at 16 (illustrating the mechanics of diamond credit transactions). The limited efficacy of public courts plays a critical, yet chiefly underappreciated, role in provoking the emergence of private law. Both the limited reach of public courts and certain aspects of contract law can explain why public courts do not sufficiently deter the inefficient breach of certain contracts.

45. Liquidity constraints and seasonal demand make credit sales central to diamond merchants. See Bernstein, Diamonds, supra note 5, at 118; Richman, supra note 7, at 16 .

46. Morning Edition: Maine Man Uses Internet to Sell Credit Information to Fish Wholesalers (National Public Radio broadcast, Jan. 29, 1999) (on file with the Columbia Law Review).

47. For an articulation of the contractual hazards in "cheek-by-jowl" transactions, which arise in just-in-time distribution networks, see Paul L. Joskow, Vertical Integration 
specified fabrics that their buyers (chiefly clothes manufacturers) demand, mills require particular grades of cotton that are difficult to measure with precision, even by industry experts. Public courts are not well equipped to determine whether a particular sample of cotton meets the specifications agreed to by a mill operator and a cotton broker, and they certainly cannot render decisions within the time constraints required to keep a mill in operation. This lack of credible enforcement would enable cheating brokers to shirk on quality or permit cheating mills to avoid payment by claiming that quality specifications were not met.

Private legal systems, resting on reputation mechanisms, have provided instruments that rescued each of these industries from the inadequacies of the public courts, and their successes illustrate how private ordering employs enforcement tools unavailable to public courts. Public courts are largely constrained by contract law to impose remedial awards only equal to the damage done by the breaching party, ${ }^{48}$ which, under the circumstances described above, are inadequate to credibly induce compliance. When a merchant's success is predicated on a good reputation, however, the entirety of future dealings is at stake. Systems that organize a coordinated punishment-for example, the internet company Seafax ${ }^{49}$ publicizes fish buyers who have not yet paid wholesalers, ${ }^{50}$ to whom wholesalers subsequently will not sell-will credibly threaten the obligor with severe and easily administered sanctions, thus inducing compliance.

In addition, reputation mechanisms have the capacity to reach into noneconomic concerns to compel merchants to adhere to their contractual obligations. One could call this the "orthogonality principle," where a merchant's utility is a function not just of economic profits but also of other concerns that fall under a trading network's control, such as community honor or participation in community events. ${ }^{51}$ For example, cot-

and Long-Term Contracts: The Case of Coal-Burning Electric Generating Plants, 1 J.L. Econ. \& Org. 33, 38-39, 46-48 (1985).

48. There are, of course, some exceptions, such as punitive damages allowed by statute. One popular example is Massachusetts's commercial laws requiring good faith dealing. See Mass. Ann. Laws ch. 93A, § 2 (Law. Co-op. 1994 \& Supp. 2004). Violators of Chapter 93A are subject to multiple damages, attorneys' fees, and other costs. Id. at $\S 9$.

49. Interested readers can visit the website at http://www.seafax.com.

50. See SEAFAX Products and Services (last visited Oct. 3, 2004), at http://www. seafax.com/cgi-bin/WebObjects/Seafax.woa/wa/gotoDocument?title=seafaxproductsand services\&zsection=about\&zsubsection=none (on file with the Columbia Law Review) (describing available Seafax services).

51. Some sophisticated utility models can characterize this principle, where individuals crave both economic and community goods. See Laurence R. Iannaccone, Sacrifice and Stigma: Reducing Free-Riding in Cults, Communes, and Other Collectives, 100 J. Pol. Econ. 271, 276-83 (1992). For a useful illustration of how this innovative characterization of individual utilities can explain unusual economic and social behavior, see Eli Berman, Sect, Subsidy, and Sacrifice: An Economist's View of Ultra-Orthodox Jews, 115 Q.J. Econ. 905, 921-29 (2000). Galanter similarly observes that intimate communities hold leverage over their members that state courts do not, noting that "[c]ommunity 
ton mill operators and cotton brokers enjoy membership in an intimate society that organizes social events, wives clubs, debutante balls, and other institutionalized occasions where merchants crave recognition and participation. A reputation marked by nonpayment or delivery of poor quality will interfere with one's-and one's family's-social status and welcome at these events. ${ }^{52}$ More forcefully, the Ultra-Orthodox Jews who dominate New York's diamond industry crave participation in their communities' intimate religious rituals, celebrations, and life-cycle events. Cheating on contractual obligations leads to exclusion from community religious practices, and flight from the community-which is the primary hazard in diamond credit sales—cuts off all possible religious participation. ${ }^{53}$ In both merchant communities, a merchant's dependence on his community's resources drives his ultimate compliance with the industry's norms and private rulings. These examples of the orthogonality principle may explain the tendency to see ethnically homogeneous merchants associated with trading networks governed by private law. In individual ethnic groups, social and community networks, in addition to the merchants themselves, can coordinate punishments and induce behavior by touching sectors of a merchant's life that public courts cannot reach.

One reason the orthogonality of preferences is important in private law settings is that, otherwise, private law systems might be susceptible to an endgame problem. Where cooperation is induced by the prospects of future transactions, incentives are measurably diluted as merchants approach retirement. One response to the endgame problem is to allow merchants to bequeath their reputations to their descendants who remain in the industry. This is nearly universal in the diamond industry, where essentially all merchants have children or nephews who inherit the family business (and, moreover, no other avenue really is available for new diamond merchants to enter the industry). ${ }^{54}$ The same occurs in the cotton industry, which observes significant intergenerational transfers of family businesses and the associated reputations. ${ }^{55}$ Not all cotton merchants, however, eventually bequeath their businesses. In these instances their desires to maintain a respected status in the community compel honest behavior through their last transaction. Targeting orthogonal preferences is a useful strategy to induce contractual compliance and resolve a reputation system's endgame problem.

3. Availability of Entry. - A significant shortcoming to private law, noted above, is that it can only reach those who subscribe to it-reputa-

standing, seniority, reputation for integrity or formidability may confer capability in the indigenous setting that does not translate into capability in the official setting." Galanter, supra note 4, at 24. Similar themes are discussed in Cass R. Sunstein, Incommensurability and Valuation in Law, 92 Mich. L. Rev. 779, 782-85 (1994).

52. See Bernstein, Cotton, supra note 5, at 1745-54.

53. See Richman, supra note 7, at 38-53 (using a "club good" model to explain the motivations of diamond dealers).

54. See id. at 31-32.

55. See Bernstein, Cotton, supra note 5, at 1770 . 
tion mechanisms can only police those who place value in maintaining a good reputation. ${ }^{56}$ Thus, the reach of private law is limited to long-term players who are assured of, and who plan to pursue, a long horizon of transactions.

This leads to a critical limitation to private ordering: Reputationbased private enforcement erects sizable entry barriers. ${ }^{57}$ Because only participating long-term players have incentives to cooperate, newcomers who have not yet established a good reputation are unable to commit credibly to uphold their contractual promises. Thus, McMillan and Woodruff noted, "[t] he corollary of ongoing relationships is a reluctance to deal with firms outside the relationship."58 Even an honest merchant who has yet to demonstrate a good reputation will not be able to transact with other merchants. Merchants who want to transact with cotton mills and brokers must undergo a rigorous application process before acquiring sufficient trust to enter independently into transactions. ${ }^{59}$ The diamond industry's networks erect even stiffer entry barriers, essentially permitting only Ultra-Orthodox community members or relatives of current merchants into the trading networks. ${ }^{60}$ Moreover, these networks tend to be rather unforgiving. A merchant found to have previously missed a payment must endure significant hurdles before gaining reentrance into the trading communities.

Some networks, such as the fish wholesalers, do seem to allow entry, but in doing so they assume a different cost. Networks that open themselves to unknown merchants, assuming honesty until proven otherwise, expose themselves to cheaters, who will always be able to enter and cheat once without facing sanctions. Some relational contract networks address this problem by employing public courts to complement private order-

56. Galanter deserves credit for observing this. After noting that "indigenous communities" enjoy powers over some transactors that are unavailable to public courts, see supra note 4 and accompanying text, he writes, "the indigenous tribunal faces the problem of obtaining leverage over those who are impervious to community opinion, getting them to submit to its jurisdiction or to comply with its decisions." Galanter, supra note 4, at 26; see also Greif, Impersonal Exchange, supra note 21, at 35 (suggesting that key power of public courts is ability to police all parties).

57. Entry barriers serve to limit the threat of superior competitors. Potential entrants can introduce new technologies, which can either lower costs (and thus prices) or improve quality. Restricting entry, therefore, shelters inefficient incumbents. In short, restricting entry can elevate prices or suppress quality improvements. For a discussion of the costs of entry barriers, see Jean Tirole, The Theory of Industrial Organization 305-55 (1988). Despite the importance of entry barriers in industrial organization economics, a consensus definition and understanding has remained elusive. For a brief overview of alternative definitions through history and a useful classification of entry barriers, see R. Preston McAfee et al., What Is a Barrier to Entry?, 94 Am. Econ. Rev. 461, 461-65 (2004).

58. McMillan \& Woodruff, Dysfunctional Public Order, supra note 1, at 2454. Though the relevant study-and thus this reference-is to firms, the same of course applies to individual merchants.

59. See Bernstein, Cotton, supra note 5, at 1765 n.167.

60. See Richman, supra note 7, at 26 (noting that "nearly all [diamond merchants in New York . . . were brought into the diamond trade by close relatives"). 
ing, even though the cost of employing the public courts may exceed the potential recovery. ${ }^{61}$ Thus, open networks may enjoy lower entry barriers but assume certain corresponding costs of one-time cheaters.

Another cost associated with the relational contracting and reputation mechanisms that support private ordering is the potential for collusive behavior. Since trade in a private system occurs within a closed community comprised of traders who are linked by channels of information and communication, merchants are well positioned to collude on price or collectively deny competitive entrants access to supply networks and other necessary resources. Of course, as the number of merchants increases, coordination becomes more difficult and collusive behavior becomes less likely. ${ }^{62}$ Consequently, collusion is unlikely to be a problem in the trading networks discussed here, where large numbers of intermediaries comprise the distribution system. Although there have been antitrust challenges to certain merchant networks, including one initiated by the U.S. Department of Justice against the New York Diamond Dealers Club, ${ }^{63}$ the failure of those suits and the persistence of self-enforcement in the trading networks suggest that the dangers of inefficient collusion are slim.

In sum, systems of private ordering enjoy an assortment of administrative efficiencies over the public courts, including savings in arriving at and implementing accurate adjudications. Private ordering can also secure some contracts in cases where public courts would be toothless.

61. See McMillan \& Woodruff, Dysfunctional Public Order, supra note 1, at 2436 n.52, 2453-54. Eastern Europe's costly and inefficient public court system may serve as a supervising authority to reputation networks, thus explaining why both public courts and reputation mechanisms are simultaneously employed in that region.

Another method of managing an open system is to screen new merchants and evaluate their unknown reputations and commercial intentions through other available information before entering into transactions. Seafax, for example, compiles credit records and other publicly available financial data on prospective buyers, in addition to their payment histories, to help sellers decide with whom they will transact. See supra note 49 and accompanying text. Some similar information is made available to subscribing diamond merchants by the Rapaport Group, which publishes the Rapaport Diamond Report and other newsletters. Interested readers can visit the website at http://www. diamonds.net. However, gathering such information on unfamiliar individuals can be costly and time consuming, and thus that strategy is not always pursued. See Fafchamps, supra note 18, at 441-42 (describing how only a minority of businesses in Ghana "actively screen prospective trade credit recipients," whether by simple methods like inspecting the client's work place or more time-consuming methods of asking banks to perform informal credit checks).

62. This proposition is at the heart of Joe Bain's original concern with market concentration, which drove much of his era's industrial organization literature. See Joseph Bain, Barriers to New Competition 27-29 (1965); see also Tirole, supra note 57, at chap. 6.

63. See Alfred J. Lubin, Diamond Dealers Club: A Fifty Year History 14 (1976) (describing antitrust actions against the Club in the aftermath of World War II, which ultimately led to only a minimal fine). 
There are, however, corresponding costs to employing private ordering, including restricting entry and (to a lesser extent) inviting collusion. ${ }^{64}$

\section{B. Firms Versus Markets}

In transaction cost economics, the paradigmatic issue is the "makeor-buy" question (alternatively coined the question of vertical integration), which asks whether a particular transaction will occur inside or outside the parameters of a firm. The inquiry begins by articulating the structural attributes of firms, markets, and other alternative forms of economic organization-where each enjoys strengths, for which transactions each structure is well suited, and what inherent tradeoffs are involved in an economic actor's selection of one form over another. ${ }^{65}$

It is critical to note at the outset that there is some significant overlap between the literature's comparison of firms and arms-length market transactions and the above discussion comparing public and private law. Many of the cost savings that private law enjoys over public law are also enjoyed by firms. Firms can secure hazardous transactions that contract

64. McMillan \& Woodruff, Dysfunctional Public Order, supra note 1, passim, also discuss noneconomic costs associated with relational contracting, such as bigotry and persistent discrimination. Richard McAdams employs game theory to illustrate how trustbased relational transactions can fuel bigotry and cause both economic and noneconomic costs. Richard H. McAdams, Cooperation and Conflict: The Economics of Group Status Production and Race Discrimination, 108 Harv. L. Rev. 1003, 1029-33 (1995). George Akerlof presents useful models explaining how customary forms of discrimination lead to adverse economic consequences. George A. Akerlof, A Theory of Social Custom, of Which Unemployment May Be One Consequence, 94 Q.J. Econ. 749, 750-53 (1980); George A. Akerlof, Discriminatory, Status-Based Wages among Tradition-Oriented Stochastically Trading Coconut Producers, 93 J. Pol. Econ. 265, 272-75 (1985).

For an alternative perspective on the effect of entry barriers on private legal systems, see Robert D. Cooter, Decentralized Law for a Complex Economy: The Structural Approach to Adjudicating the New Law Merchant, 144 U. Pa. L. Rev. 1643, 1688-89 (1996) [hereinafter Cooter, Decentralized Law] (articulating some potential benefits to a decentralized system of law, where courts find locally optimal rules by enforcing locally developed norms). Where entry barriers to merchant communities prompt the creation of additional communities with competing norms, Professor Cooter's analysis suggests that such barriers may have beneficial consequences. Id. at 1688-89.

Private legal systems that rely on social norms for enforcement and substantive law run the risk of an additional cost: the possibility that they have selected inefficient norms. Eric Posner suggests that such a possibility is not insignificant. Eric A. Posner, Law, Economics, and Inefficient Norms, 144 U. Pa. L. Rev. 1697, 1698 (1996). Alan Schwartz and Robert Scott warn more specifically that private legal systems are likely to succumb to powerful interest groups and employ rules that are favorable to those private interests but are socially unfavorable. Alan Schwartz \& Robert E. Scott, The Political Economy of Private Legislatures, 143 U. Pa. L. Rev. 595, 624-37, 644-45 (1995).

65. See generally Oliver E. Williamson, Markets and Hierarchies: Analysis and Antitrust Implications (1975) (analyzing powers and limits of market organization and hierarchical organization); Williamson, EIC, supra note 8. For a review of the widespread applications of the transaction cost approach, see Shelanski \& Klein, supra note 8, at 341-50 (1995); see also Boerner \& Macher, supra note 8, at 10-35 (reviewing transaction cost economics literature). 
law or unrestricted markets cannot guarantee and thus provide the transactional assurance that, as McMillan and Woodruff properly noted, is so craved by businesspeople. ${ }^{66}$ Moreover, firms develop personnel with the same industry expertise that private legal systems find so useful in adjudicating disputes; firms implement specialized rules to organize their internal transactions and routines to address their particularized economic objectives; and firms can operate by fiat, thus implementing decisions with speed and without external procedural barriers. ${ }^{67}$ Consequently, the features the private ordering literature identifies when extolling the virtues of private legal systems - transactional security, expertise, tailored rules, and speed-are all exhibited by firms.

This similarity reveals one of the most glaring problems of the legalcentric private ordering literature. When informed by the theory of the firm, the catalogued benefits of private over public ordering are insufficient to explain a rejection of public courts. Since a firm can achieve many of the same efficiencies that private legal systems enjoy, why do certain industries nonetheless rely on private ordering instead of organizing themselves within vertically integrated firms? The answer lies in the reciprocal cornerstone of transaction cost theory: The chief advantage market-based organization enjoys over internalizing transactions inside a firm is the market's capacity to maintain high-powered incentives, a consideration that has been conspicuously left out of the private ordering literature.

Understanding the role of incentives involves an application of rudimentary institutional economics. According to transaction cost theory, firms enjoy strong administrative controls, but they also dilute market incentives and filter market information. Because of this dilution and filtration, agents acting inside a firm are less sensitive and responsive to changes in price or demand than are corresponding autonomous agents. ${ }^{68}$ Market actors, more than firm actors, have greater exposure to market information and greater incentives to collect and then promptly act on relevant information. This feature of markets, which supplies an important comparative advantage over hierarchies, has been described by Friederich Hayek and Oliver Williamson as "spontaneous governance," 69 where incentives are in place "to provide inducements which will make

66. See McMillan \& Woodruff, Dysfunctional Public Order, supra note 1, at 2421.

67. For a detailed articulation of the transactional benefits of firms, see Williamson, MOG, supra note 10, at ch. 4; Williamson, EIC, supra note 8, at chs. 3-4. Many of the organizational benefits of firms discussed here are similarly identified in W. Richard Scott, Organizations (3d ed. 1992) and the classic Chester I. Barnard, The Functions of the Executive (18th ed. 1968).

68. Oliver Williamson attributes a firm's incapacity to mimic market incentives to "the impossibility of selective intervention" on the part of managers and the "Fundamental Transformation," in which nonspecific relationships acquire specificity when internalized within the firm. Williamson, MOG, supra note 10, at 49-50. For a detailed discussion of the costs of bureaucracy, see Williamson, EIC, supra note 8 , at ch. 6 .

69. Williamson, EIC, supra note 8 , at 125. 
the individuals do the desirable things without anyone having to tell them what to do."70 Consequently, internalizing a transaction inside a firm involves trading high-powered incentives and the capacity for spontaneous adjustment for transactional assurance. Transactions where agreements are particularly difficult to secure are more likely to occur inside firms, but transactions that present fewer enforcement difficulties are more efficiently organized in markets where information is freely disseminated and high-powered incentives are not diluted. ${ }^{71}$

In sum, transaction cost theory reveals the advantage that private ordering enjoys over firms: While both private ordering and firms are capable of providing greater transactional assurance than public courts, private ordering systems operate with autonomous economic agents and, unlike firms, neither dilute market incentives nor filter market information. On the other hand, the corresponding costs of private law are the entry barriers associated with reputation mechanisms, which firm-based exchange does not erect. So, within the structural comparison between private law and firms lies the tradeoff of diluted incentives versus entry barriers.

\section{Summary}

Incorporating the principles discussed in this Part into a single analysis is fairly straightforward. First, the private ordering literature and transaction cost theory detail several advantages that both private ordering and vertically integrated firms enjoy over arms-length transactions that are enforced in state courts: greater transactional assurance, expert adjudication, and expedient dispute resolution. Second, the private ordering literature observes that merchant communities that rely on self-enforcement must assume the costs of entry barriers, which is a cost that does not hinder industries relying either on vertical integration or the public courts. And third, the benefits of high-powered incentives that market organization enjoys over firm-based organization reflect the advantages of exchange between autonomous agents, whether within private ordering systems or public courts, over exchange within the integrated firm. The lessons from this Part are summarized in Figure 1.

70. F.A. Hayek, The Use of Knowledge in Society, 35 Am. Econ. Rev. 519, 527 (1945). Hayek, in emphasizing the economic centrality of information, emphasized that the solution requires a minimization of hierarchical control:

If we can agree that the economic problem of society is mainly one of rapid adaptation to changes in the particular circumstances of time and place, it would seem to follow that the ultimate decisions must be left to the people who are familiar with these circumstances . . . . We must solve it by some form of decentralization.

Id. at 524; see also Williamson, MOG, supra note 10, at ch. 6 .

71. In part because transaction cost economics generates such parsimonious hypotheses, its empirical applications are widespread. See Shelanski \& Klein, supra note 8, at 335-36; Boerner \& Macher, supra note 8, at 11-35. 
Figure 1-Institutional Alternatives and Associated Attributes

\begin{tabular}{|l|c|c|c|}
\hline & $\begin{array}{c}\text { Public Law, } \\
\text { Arms-Length } \\
\text { Exchange }\end{array}$ & $\begin{array}{c}\text { Private Law, } \\
\text { Reputation } \\
\text { Mechanisms }\end{array}$ & $\begin{array}{c}\text { Vertically } \\
\text { Integrated } \\
\text { Firm }\end{array}$ \\
\hline $\begin{array}{l}\text { Transactional Security; } \\
\text { Low-Cost Enforcement }\end{array}$ & - & + & + \\
\hline Allows Entry & + & - & + \\
\hline High-Powered Incentives & + & + & - \\
\hline
\end{tabular}

Importantly, Figure 1 contains some refutable hypotheses and assists in developing a positive theory of private law. The model predicts that private ordering is comparatively superior to firms and public ordering for industries that confront difficult-to-enforce transactions, are particularly sensitive to high-powered incentives, and do not prohibitively suffer when entry is limited.

\section{A Test with Preliminary Evidence}

The most straightforward test of Figure 1 is to determine whether its hypotheses comport with the findings of the budding private ordering literature. Unfortunately, as was noted in Part I, much of the private law literature examines systems in institutional settings where public courts are not an available option. But some systems of private law do emerge in settings where contract law is available, thereby providing material for a preliminary test. ${ }^{72}$ This Part continues to pay particular attention to two merchant communities that have appeared throughout this Essay-New York's diamond merchants and Memphis's cotton brokers. It then relates the model to a category of trading networks that employs private ordering to organize brokerage activities. The structural similarities underlying the privately governed merchant communities suggest some robustness to the model.

\section{A. Diamonds}

The enigmatic diamond industry has systematically rejected public courts and instead polices its merchants through private ordering and nonlegal sanctions. ${ }^{73}$ Consistent with the model, the industry's arrival at private ordering is explained by the difficulty of enforcing diamond

72. Of course, collecting empirical material from previous studies likely suffers from a self-selection problem. See supra text accompanying notes 31-32. For that and other reasons, the empirical test conducted here can serve illustrative purposes only.

73. The diamond industry is the beneficiary of three in-depth studies: Bernstein, Diamonds, supra note 5; Roy W. Kenney \& Benjamin Klein, The Economics of Block Booking, 26 J.L. \& Econ 497 (1983); and Richman, supra note 7. These three works serve as the foundation for this Part. Additionally, Yoram Barzel offered earlier examinations in Yoram Barzel, Some Fallacies in the Interpretation of Information Costs, 20 J.L. \& Econ. 
credit sales, the particular importance of high-powered market incentives, and the relatively low costs of entry barriers.

First, the diamond sale is an extreme instance of a hazardous transaction. Merchants can valuably expand their inventory if they make purchases on credit, so sales are predominantly implemented by executory contracts in which a buyer takes possession of a valuable cache of diamonds before making payment. In addition, a similar separation between possession and ownership results from the industry's significant utilization of brokers, who aggressively market diamonds they do not own to assorted buyers. ${ }^{74}$ However, diamonds' portability, concealability, and universally precious value make the risk of theft acutely high and extremely costly, leading the industry to develop forceful private mechanisms to induce credit payment and deter theft. Entry is permitted only to members of intergenerational firms, who expect they will bequeath their family business to their descendants, and to Ultra-Orthodox Jews, ${ }^{75}$ who depend on community religious goods in addition to market commodities. Those who are permitted to participate in the industry are therefore subject to a rigorous reputation mechanism, in which bad actors and their descendants are proscribed from future transactions and denied participation in community religious activities. The threat of these indefinite and noneconomic sanctions is sufficient to induce contractual compliance and transactional security.

Second, adding value in diamond sales is a process that is largely dependent on collecting market information, exposure to market pressures, and the capacity for spontaneous adaptation. The broad assortment of possible cuts, polishing techniques, jewelry settings, and subjective judgments infuses substantial variation and uncertainty into how end consumers will value a given diamond. This subjective valuation means that finding an optimal buyer for a specific stone is a very profitable enterprise. However, a buyer needs to examine a diamond personally and carefully in order to arrive at a personal valuation, so executing sales requires searching for prospective buyers and bringing diamonds to them for inspection. This matching process-the search for the "right" buyer-is very sensitive to effort. Sellers and brokers must gather market information regarding buyer demand and pair their idiosyncratic needs with the distinct qualities of available stones. In fact, the trading floor of the Diamond Dealers Club reveals a sea of high-powered incentives, where brokers invest substantial effort in determining what a prospective

291, 304-05 (1977) and Yoram Barzel, Measurement Cost and the Organization of Markets, 25 J.L. \& Econ. 27, 32 (1982).

74. For illustrations of the importance of time-inconsistent exchange in certain industries, see supra notes 44-46 and accompanying text.

75. New York's diamond industry relies predominantly on Ultra-Orthodox Jews, but other homogeneous, insular ethnic communities that exhibit similar features also play important roles in the global industry. See Richman, supra note 7, at Part IV. 
buyer needs and convincing that buyer to examine available diamonds. Fervor, intensity, and zeal characterize the DDC's swirl of trading activity.

The costs of bureaucracy and the benefits of the diamond industry's market-based organization are immediately evident from the typical instance of a potential diamond buyer announcing a need to purchase stones of certain characteristics. Since buyers overwhelmingly require that they be allowed to personally inspect a stone before committing to a purchase, the sale will go to the first seller who can present the buyer with an adequate diamond. Diamond sellers are best able to respond to this necessity for spontaneous adaptation when they are either principals in family-run businesses or self-employed brokers of those family businessmen-parties who are in possession of stones for purchase and have authority to execute a sale swiftly. A large firm whose salespersons would need to report a sales opportunity to an executive and then obtain the executive's authorization for the sale would get beaten by the swifter competition. Moreover, since the DDC serves as a central bazaar for diamond sales, few benefits come from employing large sales forces. While most competitive industries place a premium on agility, the nature of diamond sales-where demand is idiosyncratic and difficult to codify, merchandise requires in-person inspection, and goods are easily portable and extremely valuable-leads to unusually large efficiencies from spontaneous adaptation. These efficiencies induce market-based organization.

Lastly, the diamond industry does exhibit entry barriers, with participation in the industry sharply limited (with nearly no exceptions) ${ }^{76}$ to family members of current merchants and to members of ethnically homogeneous communities, particularly Ultra-Orthodox Jews. However, the costs of limiting entry are relatively small.

First, the numbers of merchants in various diamond centers approach levels where collusion or coordination would be difficult, even with the assorted community connections that members share. The New York Diamond Dealers Club, for example, is home to two thousand members.

Second, technological innovation has played a relatively small role in the industry's history. Diamond cutting employs essentially the same processes - manually applying a stone to a grinding wheel-that sixteenth century cutters used. Modern, large-scale techniques to polish diamonds have only been successful for very small stones that do not command significant values, thereby not really infringing on the Diamond Dealers' core market. Moreover, the process of selling a diamond has always required in-person inspection and sales, preventing any marketing economies of scale. Certification and grading by the Gemological Institute of America (GIA) and other grading organizations can suggest a 
stone's value, but these processes still leave room for substantial variation, forcing buyers to continue resorting to in-person purchases. ${ }^{77}$

Third, and perhaps most importantly, entry into the diamond industry is limited for only one particular channel of distribution, as the path from mine to jewelry manufacturer need not pass through the DDC's Jewish merchants. The distribution attempts by internet marketers reveal that entry, in fact, is not limited for those who want to distribute diamonds through alternative channels. Additionally, the industry has witnessed entry by ethnic groups who have been able to mimic or adopt the private ordering mechanisms employed by Jewish merchants. ${ }^{78}$ But the continued predominance-over several centuries-of Jewish and ethnic networks suggests that the survival of those networks is a function of their superiority over, not their insulation from, market challengers.

In sum, the diamond industry requires unusually forceful contractual enforcement, benefits significantly from high-powered market incentives and free access to market information, and does not suffer significantly from entry barriers.

\section{B. Cotton}

America's cotton industry also polices its own merchants. ${ }^{79}$ Most merchant-to-mill transactions are governed by the Southern Mill Rules, which are adopted and administered by trade associations that represent both merchants and mills. Merchant-to-merchant transactions are chiefly governed by the rules of the Memphis Cotton Exchange or one of four regional cotton shippers' associations. These rules, however, merely provide a framework for a reputation mechanism, where arbitration panels determine and publicize the identities of parties who breach their agreements. Wrongdoers are then rejected as members of the merchant associations, thus precluding them from future industry business, and subjecting them to nonlegal sanctions that include social ostracism from Memphis's Old South community.

Like the diamond industry, the cotton industry employs transactions that are difficult to enforce and that rely on high-powered incentives, and its brokerage system imposes relatively low costs from entry barriers. Cotton mills operate best when they are in continual operation, and so mill operators rely on a steady influx of cotton. However, since cotton is costly to store, mill operators supervise a just-in-time, or cheek-by-jowl, system of supply contracts where new quantities of cotton are scheduled

77. See Russell Shor, Diamond Grading Reports: Flawless or Imperfect?, Jewelers' Circular Keystone, July 1995, available at http://www.gemology.ru/cut/english/diamgrad. htm (on file with the Columbia Law Review) (noting that "[i]t's no trade secret that diamonds can get different grading reports or 'certificates' from different labs—or even the same lab").

78. See Richman, supra note 7, at Part V.

79. This Part relies predominantly on Bernstein, Cotton, supra note 5. 
to arrive just as the previous shipment is depleted. ${ }^{80}$ In addition, cotton mills, depending on their customer orders, require very particular grades and qualities of cotton that are difficult to predict in advance. While previewing samples may be helpful, buyers are generally required to rely on the characterizations they receive from merchants. A late shipment or a shipment of the wrong quantity, grade, or quality can be extremely costly to the mill operator, making precise contractual compliance extremely important.

Classic transaction cost theory would predict that the dangers of noncompliance would induce vertical integration, where cotton mills would integrate backwards and employ their own army of merchants. ${ }^{81}$ Such a strategy, however, would sacrifice some incentive intensity for contract security. Like the diamond industry, a cotton broker's effectiveness is very sensitive to effort. The supply chain for cotton mills involves a matching process, much like searching for the optimal diamond buyer, where brokers search for specific kinds of cotton to meet a mill's particularized needs. Brokers need to gather market information to discover buyers' needs and determine which sources can meet those needs. Vertical integration dilutes the incentives to gather and execute on such market information, and transaction cost theory suggests that such a dilution would produce a significant loss in efficiency.

Also like the diamond industry, the cotton brokerage system would benefit little from the infusion of new brokers. The large number of current brokers would have a difficult time colluding. Additionally, the buyer-seller matching process does not suffer from logjams or technological backwardness, which normally are the market inefficiencies that tempt new entrants. Moreover, the real benefits from entry would come from competition from alternative distribution systems, not alternative distributors-systems against which the private ordering system does not erect any barriers. Like diamonds, cotton grading requires in-person inspection, so buyers will either have to evaluate their own purchases or continue to trust the reputations of those from whom they buy.

\section{Global Middlemen: California's Mexican Merchants, Eleventh-Century Maghribi Traders, and Malaysia's Chinese Networks}

The structures of the diamond and cotton industries are strikingly similar. In addition to relying on similar kinds of transactions, where the costs of contract breach are unusually high, both industries rely on a brokerage system to gather market information and execute value-creating

80. See Joskow, supra note 47, at 38 (explaining cheek-by-jowl system and its value).

81. Another vertical integration option would be for mills to own their sources of cotton. However, since mills require a specific cotton grade to fulfill each customer order, they would need access to a broad collection of cotton sources to meet varying demand. A cotton mill pursuing vertical integration would have to own and maintain access to a large and diverse supply of cotton, which would be commercially infeasible given cotton's high storage costs. 
matches between buyers and sellers. This matching system is an interestingly common feature in the private ordering literature. Karen Clay's examination of California's Mexican merchants living in the 1830s and 1840s uncovers a system where Mexican middlemen structured a nexus of trade in a remote frontier for distant merchants. ${ }^{82}$ Using a reputation mechanism to police their colleagues, the Mexican intermediaries brokered purchases and sales for ships that brought goods from Boston, Mexico, the Hawaiian Islands, and South America. Similarly, Avner Greif's seminal work on the eleventh-century Maghribi traders uncovers a system of intermediaries in which the Maghribis used their cross-Mediterranean connections with each other to broker sales of goods to distant markets. ${ }^{83}$ Lastly, Janet Landa's exploration into the commercial networks in Southeast Asia uncovers ethnic communities of intermediaries who facilitate transactions for distant traders. ${ }^{84}$ These traders rely on reputation mechanisms and community sanctions to ensure that their members resist the significant temptation to steal the goods they are brokering.

The model developed here can explain the predominance of brokerage systems, or middlemen, in the private ordering literature. Economic actors in these systems create value by gathering market information so as to match optimally available goods with buyers' demands. Their value creation is driven by the efficient dissemination and collection of information, a process best organized within a market structure and one that is very sensitive to effort. In addition, the duties of an intermediary typically include taking possession of valuable goods that one does not own, which in turn creates substantial transactional hazards for their counterparts. This problem is partially solved by the middlemen's repeat participation and embeddedness in the merchant community, which support a reputation-based private ordering system that enforces contractual compliance. And even though their systems of private enforcement erect barriers to others who would otherwise serve as brokers, their merchant community suffers few costs from restricting entry so long as a critical mass of merchants remains. The model suggests that these are the merchant communities that are most likely to employ private ordering to enforce agreements.

The similarities among these different merchant networks lend additional support to Landa's broad "Ethnically Homogeneous Middleman Group" theory, which describes how ethnic groups can operate distribu-

82. Clay, supra note 17 , at $202-03$.

83. Greif, Contract Enforceability, supra note 13, at 535-42; Greif, Reputation and Coalitions, supra note 13 , at $858-59$.

84. Janet T. Landa, A Theory of the Ethnically Homogeneous Middleman Group: An Institutional Alternative to Contract Law, 10 J. Legal Stud. 349, 349-51 (1981) [hereinafter Landa, Middleman]. See generally Janet T. Landa, Trust, Ethnicity, and Identity (1994) (providing "a unifying theoretical framework to explain such diverse exchange institutions as contract law, ethnic trading networks, and gift-exchange"). 
tion networks at lower transaction costs than less homogeneous groups. ${ }^{85}$ One important element that is surprisingly missing from Landa's theory, however, is an explanation for why these ethnic networks assume the roles of middlemen-brokers who create value through a process of matching a buyer with a seller-rather than other roles in the economy. The model described here fills that hole. The matching process in brokerage systems presents severe transactional hazards, but it relies on the incentive intensities and information availability that typify market organization. Consequently, an ethnic group's capacity to self-enforce contracts is put to optimal use when group members act as intermediaries. In short, ethnic networks excel at providing brokerage systems for the same reason that the diamond and cotton industries have turned to private ordering.

\section{Social Norms and Professional Norms}

In Order Without Law, Robert Ellickson articulated "A Hypothesis of Welfare-Maximizing Norms," which argued that "members of a tight-knit group develop and maintain norms whose content serves to maximize the aggregate welfare that members obtain in their workaday affairs with one another." 86 Ellickson argued that these norms maintain a system of social control similar to how contracts enable a promisee to induce certain behavior from a promisor, where the substantive norms that emerge are those that bring mutual gain to all community members. ${ }^{87}$ Why, then, did the residents of Shasta County employ social norms and private ordering (or, in Ellickson's vocabulary, self-help) to maximize their social welfare rather than entering into a multilateral contract, enforceable by the public courts? The immediate answer is that the coordination, negotiation, and administrative costs necessary to form such a contract would be prohibitive compared to the individual gains from the maximizing norms. This explanation evaporates, though, if a social norm is viewed as the product of an implicit multilateral contract-after all, a norm is effective only if it is supported by a collective commitment. Viewing Shasta County norms through "the lens of contract" 88 reveals how the implications from this Essay apply to a larger set of social and professional norms.

85. Landa, Middleman, supra note 84, at 359-61.

86. Ellickson, supra note 11, at 167 (emphasis omitted). Ellickson notes that many earlier scholars, from varying disciplines, advanced similar propositions. See id. at 167 n.1.

87. Id. at $123-36$.

88. Oliver E. Williamson, The Lens of Contract: Private Ordering, 92 Am. Econ. Rev. Papers \& Proc. 438, 438 (2002) (observing that "mutuality of advantage from voluntary exchange is ... the most fundamental of all understandings in economics . . . [and] is better realized by examining economics through the lens of contract rather than the lens of choice" (citing James M. Buchanan, A Contractarian Paradigm for Applying Economic Theory, 65 Am. Econ. Rev. Papers \& Proc. 225 (1975))). 
A wealth-maximizing norm essentially is a tacit agreement to engage in mutually beneficial wealth-maximizing behavior - an implicit quid pro quo. ${ }^{89}$ The difference between wealth-maximizing norms and wealthmaximizing contracts ${ }^{90}$ lies not in the substance of the underlying agreements (since both outline the contours of maximizing behavior) but instead lies in how the agreements are enforced-contracts are traditionally enforced by courts, whereas norms are policed by self-enforced social sanctions. Accordingly, a tight-knit community's use of private ordering parallels a merchant community's development of a private legal system with privately enforced sanctions.

Consistent with the predictions of the model described in Part II, Shasta County's ${ }^{91}$ use of self-enforced norms-instead of publicly enforced law or vertical integration-is driven by the reduced costs and reliable efficacy of private enforcement, the relative insignificance of entry barriers, and the role of incentives. First, Shasta residents' use of social sanctions to punish defectors, chiefly through the dissemination of truthful negative gossip, avoids the very significant costs of litigation. In addition, residents understand that future interactions with their neighbors will offer opportunities to reciprocate accidental harms (i.e., your cattle graze on my pasture today, and mine will likely graze on yours tomorrow), thereby enabling them to avoid conflicts altogether. ${ }^{92}$ Thus, gossip and mental accounting serve as inexpensive enforcement devices that remain highly effective because neighbors strongly desire to main-

89. Implicit quid pro quos can alternatively be described as iterated prisoner's dilemma problems, where a collective commitment to a tit-for-tat strategy-in which cooperative behavior is rewarded with reciprocal cooperation while defection is threatened with sanctions-will sustain mutually welfare-maximizing behavior. See generally Robert Axelrod, The Evolution of Cooperation 206-07 (1984).

Most of the economics and philosophy literature define norms as obligations to engage in certain behavior, subject to the threat of sanctions. See, e.g., Cooter, Structural Adjudication, supra note 4, at 229 n.28 (describing the canonical form of a norm as "an obligation (norm's character) to do something (norm's act) in certain circumstances (norm's conditions), subject to a penalty for noncompliance (norm's sanction)" (citing Georg Henrik von Wright, Norm and Action: A Logical Enquiry passim (1963))). Perhaps norms differ from contracts in that contracts are products of explicit agreements whereas norms are internalized, see id. at 220-21, but even that difference is immaterial if the distinction between explicit and implicit agreements is blurred. More importantly, the explicitness of contract formation does not determine either the substance of the underlying agreements or the instruments through which those agreements are enforced.

90. Alan Schwartz and Robert Scott articulate a normative theory suggesting that contracts between commercial agents should be viewed as wealth-maximizing endeavors, and contract law should interpret them accordingly. See Alan Schwartz \& Robert E. Scott, Contract Theory and the Limits of Contract Law, 113 Yale L. J. 541, 544 (2003) (" $[\mathrm{C}]$ ontract law should facilitate the efforts of contracting parties to maximize the joint gains (the 'contractual surplus') from transactions.”). Understanding norms as implicit multilateral contracts might suggest that the applicability of Schwartz and Scott's theory extends into the study of norms as well.

91. Though this discussion pertains to Ellickson's description of Shasta County, the conclusions can be generalized to other close-knit communities.

92. Ellickson, supra note 11, at 55-62; see also supra note 89 . 
tain positive long-term relations with each other and their community. ${ }^{93}$ Second, and relatedly, the costs of entry barriers from relying on private ordering are insignificant since the community population remains largely stable. And third, ownership of land by individual families, rather than integrated ownership, strengthens market incentives on property owners. Though perhaps absurd to consider in the context of Shasta County, vertical integration would place the whole county under a single owner, and residents would rent under leases that define renters' rights. Such a rental scheme would preemptively resolve neighborly disputes, but the bureaucratic costs of centralized ownership would dilute much of the land's value.

The model can be similarly applied to professional communities that disseminate professional, mutually wealth-enhancing norms of conduct. One such community that has benefited from valuable examination is Silicon Valley's engineers. In Regional Advantage: Culture and Competition in Silicon Valley and Route 128, AnnaLee Saxenian observed that Silicon Valley engineers developed professional norms that emphasize sharing information, cooperating with competitors, and building collegial relationships through social and professional networks. ${ }^{94}$ Even though research-intensive firms are normally inclined to resist openness in order to protect their intellectual property, engineers refused to work for firms that were not committed to these collaborative norms-such as firms that punished employees for sharing firm information with outsiders, aggressively protected intellectual property rights through litigation, or restricted employees' ability to pursue outside opportunities. This professional ordering prevented noncooperating firms from remaining competitive. In addition, executives and employees at noncooperating firms were excluded from professional networks and many social networks, making work at those firms additionally undesirable. Saxenian argues that the California engineers' professional norms led both to their collective benefit and to the region's tremendous economic growth. ${ }^{95}$

93. Importantly, the efficacy of self-enforcement is contingent on the certainty of a long horizon of future interactions, and Ellickson explicitly observes that residents resorted to formal litigation in public courts when one of the parties was not embedded and socially invested in the community. Ellickson, supra note 11, at 62-64.

94. AnnaLee Saxenian, Regional Advantage: Culture and Competition in Silicon Valley and Route 128, at 30 (1994). Alan Hyde similarly observes that engineering firms that sue departing employees for violating covenants not to compete or trade secret agreements suffer reputational damage, have difficulty recruiting new employees, and experience diminished internal morale. See Alan Hyde, Working in Silicon Valley: Economic and Legal Analysis of a High-Velocity Labor Market 40 (2003) [hereinafter Hyde, Trade Secrets] (concluding that trade secret suits against departing employees harm plaintiff companies in various ways while "rarely accomplish[ing] anything"); Alan Hyde, Silicon Valley’s High-Velocity Labor Market: When Labor Markets Work Like Information Markets, 11 Bank Am. J. Applied Corp. Fin. 28, 32 (1998) (highlighting such damages in the case of Intel).

95. See Saxenian, supra note 94, at 30. But see Hyde, Trade Secrets, supra note 94, at 33 (attributing, in part, Silicon Valley's open environment and positive spillovers, and 
This emphasis on openness generated positive spillovers from innovation, a more efficient labor market, and a reduced time-to-market period for many new technologies. ${ }^{96}$ Massachusetts's technology corridor along Route 128, the Valley's chief competitor, was home to a very different professional culture featuring a much more closed environment, rendering it unable to match Silicon Valley's growth.

Silicon Valley engineers pursued this enforcement path-declining to codify their norms in formal multilateral contracts and instead enforcing their commitment to mutually beneficial behavior through professional and social exclusion-for primarily the same reasons Shasta County residents relied on self-enforced norms. Enforcement through private ordering is far less costly than litigation, entrants into the profession are as committed to the same professional norms as current engineers and therefore do not threaten the reigning professional culture, and vertical integration would lead to prohibitive bureaucratic costs. The same logic can be applied to a long list of other professions with mutually beneficial, wealth-enhancing norms. ${ }^{97}$

A collective commitment to a similar set of professional norms has recently enabled software engineers to organize in an unusual and highly effective system of production. The open source software movement, discussed in Yochai Benkler's Coase's Penguin, or, Linux and The Nature of the Firm, ${ }^{98}$ introduces an interesting twist to the traditional market-versus-firm paradigm because free software projects "do not rely either on

subsequent economic growth, to the refusal of California judges and juries to enforce trade secret law); Ronald J. Gilson, The Legal Infrastructure of High Technology Industrial Districts: Silicon Valley, Route 128, and Covenants Not To Compete, 74 N.Y.U. L. Rev. 575 , 578 (1999) (crediting California's refusal to enforce noncompete contracts with fueling state's technology employment growth).

96. See Tracy R. Lewis \& Dennis A. Yao, Innovation, Knowledge Flow, and Worker Mobility 4-5 (May 2003), available at http://rider.wharton.upenn.edu/ yao/ SVsubmitjune03.pdf (on file with the Columbia Law Review) (identifying certain efficiencies when engineers can command a commitment to openness from employers and explaining that firms consequently will adopt open environments to recruit employees in a tight labor market).

97. Two other scholars have similarly observed that when scientists collectively commit to professional norms of cooperation, they are able to force their employers to foster open environments that permit sharing research. Under such a regime, scientists benefit from collaboration and enjoy the rents of more efficient research. Paul David writes that, historically, scientists have been able to establish "open science institutions" when they have negotiation leverage over prospective employees. See Paul A. David, Common Agency Contracting and the Emergence of "Open Science" Institutions, 88 Am. Econ. Rev. 15, 19 (1998). Arti Rai also reports that early molecular biologists developed professional norms of "communalism" where "[p] roperty rights in science are whittled down to a bare minimum by the rationale of the scientific ethic." See Arti Kaur Rai, Regulating Scientific Research: Intellectual Property Rights and the Norms of Science, 94 Nw. U. L. Rev. 77, 88-90 (1999) (citing Robert K. Merton, The Normative Structure of Science, in The Sociology of Science 267, 273 (1973)).

98. Benkler, supra note 3 . 
markets or on managerial hierarchies" for organization. ${ }^{99}$ Instead, open source projects employ what Benkler called a "[c]ommons-based peer production," 100 where value-in the form of useful computer code-is created by synergies and cooperation between programmers.

Normally, scholars note, the generation of value from collaboration and coordination of inputs best occurs within a firm because outside the firm property rights are difficult to define and pro rata contributions in team production are difficult to observe. ${ }^{101}$ In the open software movement, however, programmers abide by a professional community norm where participants do not demand direct compensation for their contributions. ${ }^{102}$ The absence of demands for compensation negates the need for firm organization, yet finding the appropriate synergies-locating the programmers who create the optimal matches-is of the utmost importance. Benkler argued that the open source commons, like markets and unlike hierarchical organization, permits the wide dissemination of information and enables potential programming collaborators to find their optimal partners easily. Much as cotton suppliers find mills or diamond wholesalers find jewelry manufacturers, open source programmers em-

99. Id. at 372. But see David McGowan, Legal Implications of Open-Source Software, 2001 U. Ill. L. Rev. 241, 268-70 (arguing that open source projects rely on clusters that provide hierarchical control).

100. Benkler, supra note 3 , at 375 .

101. See Armen A. Alchian \& Harold Demsetz, Production, Information Costs, and Economic Organization, 62 Am. Econ. Rev. 777, 794-95 (1972) (describing firms as presenting most efficient model of team productive activity).

102. But see Siobhán O'Mahony, Guarding the Commons: How Community Managed Software Projects Protect Their Work, 32 Res. Pol'y 1179, 1187-91 (2003) (observing that community-managed software projects pursue both legal (chiefly licensing agreements) and nonlegal (social sanctions) tactics to protect their intellectual property rights, a protection that allows "a project's intellectual property to be publicly and freely available and yet, governable"). O'Mahony nonetheless agrees that "[i]n the eyes of both legal scholars and informants [her interviewees], the [General Public License]'s strength stems not necessarily from its legality, but from the public collective opinion of community members." Id. at 1189.

How programmers receive compensation, or more generally, why they are motivated to expend resources and effort to open source projects, is a provocative puzzle that has generated multiple explanations. See James Boyle, Fencing Off Ideas, Daedalus, Spring 2002, at 13, 23 (observing that "the Internet is one big experiment in distributed cultural production"); Josh Lerner \& Jean Tirole, Some Simple Economics of Open Source, $50 \mathrm{~J}$. Indus. Econ. 197, 199 (2002) (attempting to explain open source projects according to industrial organization and labor economics theories); Eric von Hippel, Innovation by User Communities: Learning from Open-Source Software, M.I.T. Sloan Mgmt. Rev., Summer 2001, at 82, 86 (observing growing academic focus on "phenomenon of user innovation communities" and noting subject's changing nature); Karim R. Lakhani \& Robert G. Wolf, Why Hackers Do What They Do: Understanding Motivation and Effort in Free/Open Source Software Projects 15 (M.I.T. Sloan Sch. of Mgmt., Working Paper No. 4425-03, 2003), available at http://papers.ssrn.com/sol3/papers.cfm?abstract_id=443040 (on file with the Columbia Law Review) (considering "impact of the personal sense of creativity" on software developers). 
ploy market organization to find value-creating matches. ${ }^{103}$ However, unlike markets and like hierarchies, the open source commons then provides a forum for the coordination of multiple interlocking and cooperative projects. ${ }^{104}$ This unusual system of economic organization illustrates the power of professional norms. When norms remove the desire to secure appropriability-or, as Benkler says, when "the problems of motivation" are solved ${ }^{105}$ - then the comparative advantages of both market organization and coordinated adaptation can take hold, making possible a highly effective system of production. ${ }^{106}$

In sum, Shasta County ranchers, Silicon Valley engineers, and open source programmers employ self-enforced norms to induce mutually beneficial behavior at costs that public courts cannot match and with benefits that would be lost under a public ordering regime.

\section{The Model and Its Antecedents: Transaction Cost Economics and Private Ordering}

The two bodies of literature that set the stage for this Essay, transaction cost economics and private ordering scholarship, provide both foundations and points of departure for the underlying analysis. The foundations relied upon here have been explored sufficiently in the previous Parts, but it is worth discussing in greater depth how this Essay differs from and contributes to previous work in both of those areas.

103. Benkler, supra note 3 , at 376 (noting that open source "provides a framework within which individuals who have the best information available about their own fit for a task can self-identify for the task").

104. Chester Barnard is credited for noting the capacity of hierarchical firms to induce economic cooperation. See Barnard, supra note 67, at 4 ("Formal organization is that kind of co[o]peration among men that is conscious, deliberate, [and] purposeful."). Oliver Williamson credits Barnard for sparking the "incipient science of organization" in which cooperative adaptation is recognized as a valuable attribute of hierarchical organizations. See Williamson, MOG, supra note 10, at 29-30. For a rich, and to date the most complete, discussion of the institutional attributes of commons-based property rights, see Elinor Ostrom, Governing the Commons: The Evolution of Institutions for Collective Action 27 (1990) (identifying "underlying design principles of the institutions used by those who have successfully managed their own" common pool resources).

105. Benkler, supra note 3 , at 376 .

106. Note that Benkler's article and this Essay jointly suggest that the applicability of transaction cost theory extends deeply into unusual forms of organization. Specifically, unusual systems of economic organization emerge in response to the atypical circumstances where certain aspects of markets and certain aspects of hierarchies are in demand. The model formulated here argues that private ordering emerges when the benefits of disseminating information and instituting high-powered incentives are high, the need for transactional governance is high, and the costs of entry barriers are low. Benkler's parallel analysis discusses a situation where the benefits of disseminating information and instituting high-powered incentives are high, the need for transactional governance is low, and the need for collaboration and coordinated team production is high. Both constitute useful tweakings of transaction cost theory. 


\section{A. Transaction Cost Economics}

Several economists have previously recognized that private mechanisms arise to enforce contracts where public instruments are ineffective. ${ }^{107}$ In modeling how a repeat purchase context creates a marketbased contract enforcement mechanism, Benjamin Klein and Keith Leffler challenged the "implicit assumption . . . of the legal-philosophical tradition upon which the economic model is built [that] without some third-party enforcer to sanction stealing and reneging, market exchange would be impossible."108 Oliver Williamson put the relationship directly, writing that "the incentives of private parties to devise bilateral contractual safeguards [are] a function of the efficacy of court adjudication, and ... var $[y]$ with the attributes of transactions."109 The notion that transactors successfully operate outside the law is not new.

This scholarship has produced some useful models that can explain certain instances of private ordering, but it chiefly addressed contexts that are materially different from those discussed in Parts I and III. One category of models, led by the Klein and Leffler template, depicts how market-based reputation mechanisms induce firms to comply with their pledges for high quality. ${ }^{110}$ These reputation models are limited, though, in that they illustrate only how a market can enforce quality promises by relying chiefly on separation equilibria and do not evaluate the efficiency of the market mechanism in relation to institutional alternatives. It also is significant that the models involve sales in the general flow of commerce and do not approximate actual contractual relationships between identifiable parties. Moreover, some of these models explicitly provide for free entry, which is antithetical to the realities of private ordering systems. In short, this body of literature models

107. The approach employed here and discussed throughout this Essay is one that identifies certain structural deficiencies in the public courts that private actors must overcome. It is to be distinguished from the perspective, pervasive in legal scholarship, that identifies shortcomings in the public courts and in contract law and aims to improve both. For examples of the latter, see Llewellyn, supra note 39, at 705; see also Clyde W. Summers, Collective Agreements and the Law of Contracts, 78 Yale L.J. 525, 527 (1969). For a wonderful critique of these approaches to contract law, which are embodied in the Uniform Commercial Code, see Bernstein, Business Norms, supra note 5, at 1766 (challenging UCC's philosophy of seeking "immanent business norms" in deciding cases).

108. Benjamin Klein \& Keith B. Leffler, The Role of Market Forces in Assuring Contractual Performance, 89 J. Pol. Econ. 615, 615-16 (1981); see also L.G. Telser, A Theory of Self-Enforcing Agreements, 53 J. Bus. 27, 30 (1980) (examining situations in which self-enforcing agreements may occur).

109. Williamson, MOG, supra note 10, at 122-23.

110. See David Kreps \& Robert Wilson, Reputation and Imperfect Information, $27 \mathrm{~J}$. Econ. Theory 253, 275-77 (1982) (presenting game theory models that reveal the effects of imperfect information); Paul Milgrom \& John Roberts, Predation, Reputation, and Entry Deterrence, 27 J. Econ. Theory 280, 281 (1982) (highlighting predation as a "rational, profit-maximizing strategy" and examining effects of predation on reputation); Carl Shapiro, Premiums for High Quality Products as Returns to Reputation, 98 Q.J. Econ. 659, 659-60 (1983) (modeling effect of reputation in perfect competition). 
phenomena very different from those of interest here. A closer analog is the examination of private ordering in the bilateral context, where two contracting parties elect to provide each other with the capacity to impose severe ex post sanctions should either one breach. Labeled a "hostage exchange," this latter model resembles a simplistic portrayal of the system of private ordering, where one party's capacity to inflict harm on the other party in the event of a breach, and vice versa, allows both parties ex ante to commit credibly to fulfill their obligations (the assurance of coordinated punishment in multilateral systems is the counterpart to the bilateral hostage exchange). ${ }^{111}$ The shift from the bilateral paradigm to the multilateral models discussed in Parts I and III, however, requires a distinctly different application of the transaction cost model. Chiefly, entry barriers do not factor into the analysis of bilateral private ordering. In the bilateral setting, the identity of the transactors is fixed, and the focus of the examination is on a single transactional relationship. The multilateral setting, however, sees a changing landscape of differently paired relationships in a system that organizes a multitude of transactions. The multilateral context, therefore, is longitudinal and dynamic, and the existence of entry barriers would ultimately be very costly.

The importance of entry barriers in the multilateral context, and their absence in the bilateral context, requires a revision to the unidimensional transaction cost model. The transaction cost template characterizes bilateral ordering as a hybrid that occupies an intermediate location along a unidimensional spectrum spanning from markets to firms. As such a hybrid, it enjoys greater transactional security than the unregulated market and, correspondingly, greater incentive intensity than the hierarchical firm. ${ }^{112}$ If the transaction in question requires greater governance, the transaction cost model predicts that the transactors will tend toward vertical integration, but barring a need for that additional assurance, the parties will remain autonomous and continue to enjoy the efficiencies of high-powered market incentives. In short, there is a single tradeoff between market incentives and transactional securitymarkets provide the first, hierarchies provide the second-and bilateral private ordering negotiates a certain balance between the two considerations.

Incorporating the additional variable of entry barriers into the multilateral setting, however, involves an entirely new tradeoff between entry availability and transactional security - public courts provide the first and private ordering provides the second. The consequence of adding a second tradeoff to the transaction cost paradigm requires altering the predictive template in a substantial way. Private ordering occupies not

111. See Williamson, Credible Commitments, supra note 10, at 519-22 (arguing that "the economic equivalents of hostages [are] widely used to effect credible commitments").

112. See Williamson, MOG, supra note 10, at 101-05 (noting that "hybrid mode . . . elicits strong incentives" and contains "long-term contracts [that] are supported by added contractual safeguards and administrative apparatus"). 
merely an intermediate location between markets and firms but is instead a distinct system of economic organization that requires independent comparisons with markets and firms. The analysis therefore requires use of three variables-market incentives, transactional security, and entry barriers-to evaluate three separate governance mechanisms-firms, markets, and private ordering. Depending on the needs of the underlying transaction, the model's analysis can then predict which one mechanism will excel above the others.

Put simply, moving from the bilateral to the multilateral context requires the introduction of an additional variable, availability of entry, which in turn requires consideration of a second tradeoff, entry versus transactional security. Incorporating the second tradeoff to the transaction cost model therefore requires revising the unidimensional model into the $3 \times 3$ chart depicted in Figure 1 . The result is a more nuanced and more complicated model that must account for more variables. But it also represents an extension of transaction cost theory into new territory, even while the model retains transaction cost theory's parsimonious methodology and fundamental principles.

\section{B. Private Ordering Literature}

The primary departure in this Essay from previous scholarship on private ordering lies in its comparison between private ordering and other alternatives. Two contributions are worth noting. First, the comparison here includes an assessment of the institutional competencies of the vertically integrated firm, which distinguishes this model from the "legal centralism" approach discussed in the Introduction. ${ }^{113}$ That additional consideration, which is a product of combining the private ordering literature with transaction cost theory, is at the core of this Essay and is likely its most important contribution.

The second, and less apparent, contribution lies in this Essay's placing a premium on institutional capacities to ensure transactional assurance, whereas previous works have placed a premium on administrative costs. Earlier scholarship compared the costliness of employing state courts with the efficiency, speed, and accuracy afforded by private legal systems, arguing that merchant communities opt for private ordering in order to capture these savings. Construction of a private ordering system, these works maintain, is thus a deliberate choice ${ }^{114}$ in that the state courts remain a viable but merely less preferable option, leaving private ordering in the "shadow" of otherwise enforceable law. ${ }^{115}$

113. See supra note 4 and accompanying text.

114. The classification of the deliberate choice inherent in the arrival at private ordering over public courts is evident from the title of Lisa Bernstein's seminal work, "Opting Out of the Legal System." See Bernstein, Diamonds, supra note 5.

115. See supra note 6 (discussing "shadow of the law" analyses). The vast majority of legal scholarship that examines private ordering in modern economies professes to occur within the "shadow of the law," where the law still offers a viable, though less desirable, 
However, the literature's emphasis on administrative costs is misplaced. Certainly, the prior scholarship's detailing of certain administrative savings afforded by private enforcement systems is important since those savings are far from trivial. However, as is noted in Part II, the vertically integrated firm achieves the same administrative efficiencies. Thus, while those efficiencies reveal significant insights into the shortcomings of our state courts, they cannot explain the arrival at private law. More importantly, administrative costs simply are not the relevant explanatory variable. What truly drives the creation-really, the necessity-of private enforcement systems is the incapacity of public courts to assure transactional security. Administrative savings from private enforcement are only a secondary, albeit useful, consequence that emerges after the need for private ordering becomes apparent.

The following hypothetical illustrates this last point. Suppose a merchant community requires all of its members to use contracts that, should a disagreement arise, compel disputing parties to use a private dispute resolution forum with preselected arbitrators, industry-tailored law, and strict limitations on costly components of litigation such as discovery. All such arbitration agreements would be enforceable in public courts. Courts would uphold and enforce any conclusions by the arbitrators, and pursuant to the Federal Arbitration Act ${ }^{116}$ and similar state law provisions, courts would even stay any parallel litigation before them that is subject to an arbitration agreement. ${ }^{117}$ Consequently, the industry could leave enforcement entirely to state courts while maintaining a private legal forum. This would be the best of both worlds: all the administrative savings from the privately tailored substantive law and procedures, yet no need to rely on reputation mechanisms, nonlegal sanctions, or any

recourse. See generally Ellickson, supra note 11 (investigating private dispute resolution in rural setting); Bernstein, Business Norms, supra note 5 (using merchant law to challenge "the idea that courts should seek to discover and apply immanent business norms in deciding cases"); Bernstein, Diamonds, supra note 5; Bernstein, Cotton, supra note 5; Macaulay, supra note 10 (highlighting the importance of occupational role in noncontractual business relations). Macaulay and Ellickson explicitly noted instances where the same agreements that were enforced privately were also enforced in state courts whenever one of the disputing parties was shortsighted. In contrast, examinations of private ordering in developing nations, in early America, and in illegal circles operate under the premise that there is no viable state court alternative to enforce agreements, and thus are beyond this shadow. See supra notes 19-20. The examination here is unique in that it claims to examine private ordering in modern economies that are still beyond the shadow of public courts.

116. 9 U.S.C. $\$ 1(2000)$.

117. See id. $\S 3$ ("If any suit . . be brought in any . . . court[ ] of the United States upon any issue referable to arbitration ... the court . . shall on application of one of the parties stay the trial of the action until such arbitration has been had ...."); see also Gillian K. Hadfield, Privatizing Commercial Law: Lessons from the Middle and the Digital Ages 17 (Stanford Law Sch., John M. Olin Program in Law and Econ., Working Paper No. 195, Mar. 2000), available at http://papers.ssrn.com/sol3/papers.cfm?abstract_id=220252 (on file with the Columbia Law Review) ("'Private' arbitration is a creature of contract and so is as much a matter of 'public' law as any contract."). 
other instruments of private enforcement that, necessarily, erect costly entry barriers.

However, the literature on private legal systems reveals no such mosaic of public enforcement and private dispute resolution. We instead observe private ordering accompanying private substantive law and with it the pervasive reliance on reputation mechanisms despite their significant costs. This is because administrative savings are only of secondary importance, where the primary factor driving parties towards private ordering-consistent with the transaction cost approach and the comparative institutional analysis in Part II-is the ability of courts versus other instruments to enforce agreements.

In short, the approach in this Essay departs from previous private ordering scholarship in two respects: It relates private ordering to alternative governance mechanisms, including the firm, in comparative institutional analysis, and it bases that analysis on the institutional capacities to induce contractual enforcement rather than on basic administrative costs. These are departures of significant import, and they allow for transaction cost theory to bring a firmer theoretical foundation to the budding literature on private ordering.

\section{CONCLUSION}

The literature on private law is replete with fascinating stories: fishmongers in a Congolese village berating cheaters, Ultra-Orthodox Jewish diamond merchants and their allocation of religious honors, medieval merchants organizing transcontinental trade, and the underworld of illegal activity. What the literature largely has lacked, to date, is a theoretical superstructure that unites it with other institutional theory and explains why some industries, in contrast to most, persistently reject public courts even after the emergence of a sophisticated legal system. Such a theoretical foundation is critical to developing a broader understanding of the role and utility of private ordering, and the positive model presented here takes steps towards articulating the specific circumstances where private ordering is superior to rival systems of contract enforcement. Understanding the circumstances under which merchants reject state courts will generate valuable insights into the shortcomings of those public institutions, and a systematic theory that identifies those shortcomings will, in turn, plant the seeds for a constructive agenda for institutional reform. 
